\title{
オナガの群れ生活の特質
}

\author{
細 野 㫪 夫 \\ 長野市立安茂里小学校

\section{Characteristic Features of Group Living Life of the Azure-winged Magpie Cyanopica cyana}

\author{
Tetsuo Hosono \\ Amori Primary School, 1155 Amori, Nagano 380
}

同一地域に年間定住する留鳥の生活様式は, 我が国に特いてょく研究されてきたが，そ れは大きく 2 ひ分けられる.ひとつは, 番いが年中なわばりを持つるのであり（例えば ホオジロ Emberiza cioides: 山岸 1978, YAMAGISHI 1971), 他は繁殖期には番いでなわば りに別れるが, 非繁殖期には群れで生活するすのである. 後者は, さらにカワラヒワ Carduelis sinica のように換羽期には群れとなり, 終了後は繁殖地に戻り番いを形成し, ルー ス・コロニーで繁殖するもの (中村 [浩] 1976, 1979, NAKAMURA 1979, 1982), シジュウカラ Parus major のように番いなわばりと群れ生活の時期が約半年ずつかなり明瞭に分かれる もの (SAITOU 1978, 1979a, 1979b, 1979c), エナガ Aegithalos caudatus のように一年のほ とんどを群れで過ごし，繁殖期のごく限られた時期だけに番いが析出するもの（中村 [登] 1962，1972）などとなる.

オナガ Cyanopica cyana は, 日本・中国などの東アジアとヨーロッパのポルトガル・ スペインに互いに離れて分布しているカラス科の鳥である (清棲 1952, GoodwIN 1976). 私は 1962 年からこの鳥の社会生態について調べてきたが (細野 1966a, 1966b, 1967a, 1967b, 1968, 1969, 1971a, 1971b, 1973, 1975, 1983), これらの研究の結果, オナガの生活 は一時的に群れというょりも，一年の全生活環を通して常時群れ生活をしていることが示 唆されてきた．このように年間にわたって徹底した群れ生活をするるのは, コロニー性の 鳥をのぞいて，これまでのところ世界的にもあまり例が知られていないので，本報では繁 殖期と非繁殖期を通して同一地域でみたオナガについて，その群れの実態を明らかにし， オナガの群れ生活の特質を若干の他の鳥類と比較しながら論じてみたい.

なお，オナガについては，先にあげた私の研究のほかに，葛 (1942), SANTOS (1968), ARAUjo (1975), YAMAGISHI \& FUJIOKA (1986) の報告があるが，いずれも社会生態の一 端の解明にとどまっている.

本論に入るに先立ち, 研究の当初からご指導をいただいた信州大学教育学部羽田健三名 誉教授および山階鳥類研究所研究部長の黒田長久博士, ならびに本論文をまとめるにあた って懇切丁寧な助言および校閲をいただいた大阪市立大学理学部動物社会学研究室の山岸

\footnotetext{
${ }^{1}$ 本論文は京都大学へ提出した学位論文の一部である.
} 
哲教授, 京都大学理学部動物学教室の川那部浩哉教授, 安部环哉助教授, とくに江崎保男 博士に厚く御礼申し上げる. また, 捕獲や文献についてご協力いただいた大阪市立大学理 学部動物社会学研究室の藤岡正博博士, 論文の閲覧や図の作成でご指導いただいた信州大 学教育学部の中村浩志助教授, 同時追跡の観察にご協力いただいた日本野鳥の会会員の森 野正弘・橋本昭夫 - 小林直文 - 中村公義 - 田原偉成・佐藤陵沢・荒井律子 - 荒城由美の諸 氏にも深く感謝の意を表したい.

\section{調查地と方法}

調查は長野市の日詰 (北緯 $36^{\circ} 37^{\prime} 50^{\prime \prime}$ 東経 $138^{\circ} 13^{\prime}$ ) と川中島 (北緯 $36^{\circ} 35^{\prime} 40^{\prime \prime}$ 東経 $\left.138^{\circ} 9^{\prime} 55^{\prime \prime}\right)$ の二か所で行った.

日詰には, かつて屋敷林を中心に社寺林や果樹園や耕作地が散在し, その周辺に水田が 広がっていたが, 20 年ほど前から宅地造成が始まり, 今では大半が住宅地や工場になって いる.ただ初期に造成された住宅地には小さな屋敷林が付随している (Fig. 1a). 調査は 1983 年 4 月 24 日から 1984 年 8 月 14 日にかけて 120 日間行った. 1 日 1-3 時間を かけ, 屋敷林 $\mathrm{A} ・ \mathrm{~B} ・ \mathrm{C} ・ \mathrm{D} ・ \mathrm{E} ・ \mathrm{~F} ・ \mathrm{G} ・ \mathrm{H} ・ \mathrm{I} ・ \mathrm{M} ・ \mathrm{~N} ・ \mathrm{O}$ とリンゴ園 $\mathrm{P} ・ \mathrm{Q} ・ \mathrm{R}$ はほほほ 毎回, 屋敷林 $\mathrm{J} ・ \mathrm{~K} ・ \mathrm{~L}$ は少なくとも月 2 回巡回した. オナガを発見したならばそれを追 跡し，見失ったときに巡回を再開した，また必要に応じてタイムマッピングを行った：造 巣が始まってからは, 栄材運び・抱卵・給飳や接近個体への反応, さらに移動の方向と位 置などについても観察・記録した.

川中島も日詰同様, 屋敷林を中心に社寺林・果樹園・耕作地が拡がる地域である (Fig. 1b). ここでは 1962 年 4 月 2 日から 1965 年 3 月 29 日にかけての 259 日間, さらに 1983 年 1 月 15 日から 3 月 19 日にかけての 17 日間調査を行った. 前者の調査地域は 川中島常行寺を中心とした地域で, 後者の調査地域の中央部にあたる.

1962-65 年の調查は通常は 1-2 時間をかけ, 時には終日にわたって屋敷林 $\mathrm{a} ・ \mathrm{~b}$ と果樹 園 $\mathrm{p} ・ \mathrm{q} ・ \mathrm{r} ・ \mathrm{t}$ を毎回, 屋敷林 $\mathrm{c}$ と果樹園 $\mathrm{s}$ は少なくとも月 3 回巡回した. 1983 年の調 查は, 常に 2 人以上で 3-4 時間をかけて調査地内の異った区域を巡回し, 発見したオナ ガの群れを各々の調査者が追跡する方法をとった. とくに 3 月 19 日は 9 人を投入した.

これらの日中の調查に引続き, むしくはこれとは別に, 侍および就侍行動を両調查地で 調べた. 通常日没約 2 時間前に群れまたは個体に接近し, その行動を記録した. また侍の 位置と樹種も記載した.

オナガを捕獲した場合は，羽色によって前年生まれの亜成鳥と成鳥を区別した（山階 1933, SVENSSON 1984 による). 日詰では 1983 年 6 月 13 日に色足環とビニール肩章で標 識した成鳥と亜成鳥の各 1 個体 ( $\mathrm{R}$ と $\mathrm{M}$ と名付ける) と, 尾羽の長さが極端に短い個体 （S と名付ける）とが，また 1983 年に色足環で標識した 2 巣の雛が個体識別可能であった. $\mathrm{R}$ は 1983 年と 1984 年の両繁殖期に繁殖し, その行動から雄である.とが確実である. た 1962 年から 1964 年の川中島常行寺では, 各繁殖期に 2 巣もしくは 3 巣の雛に標識し た.な拉, 複数の個体がかたまって連続的に同一の行動をとった場合に、これを群れとみ なした. 


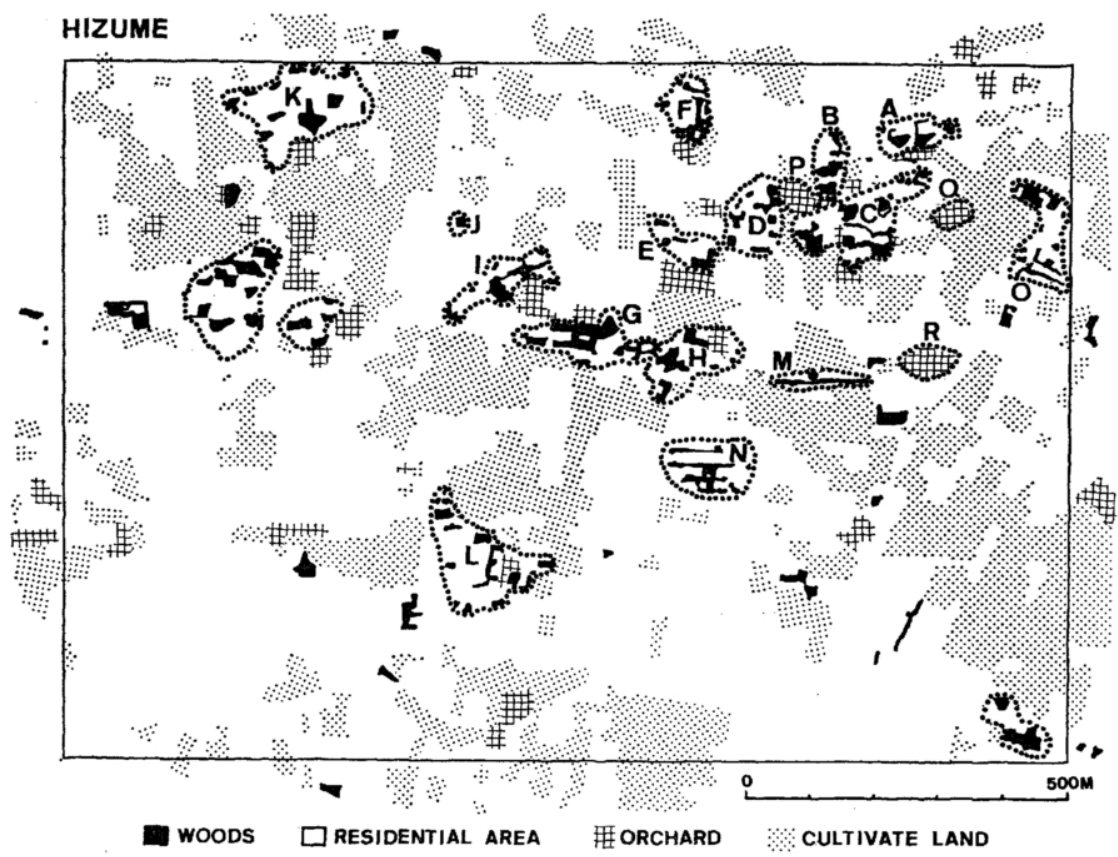

(a)

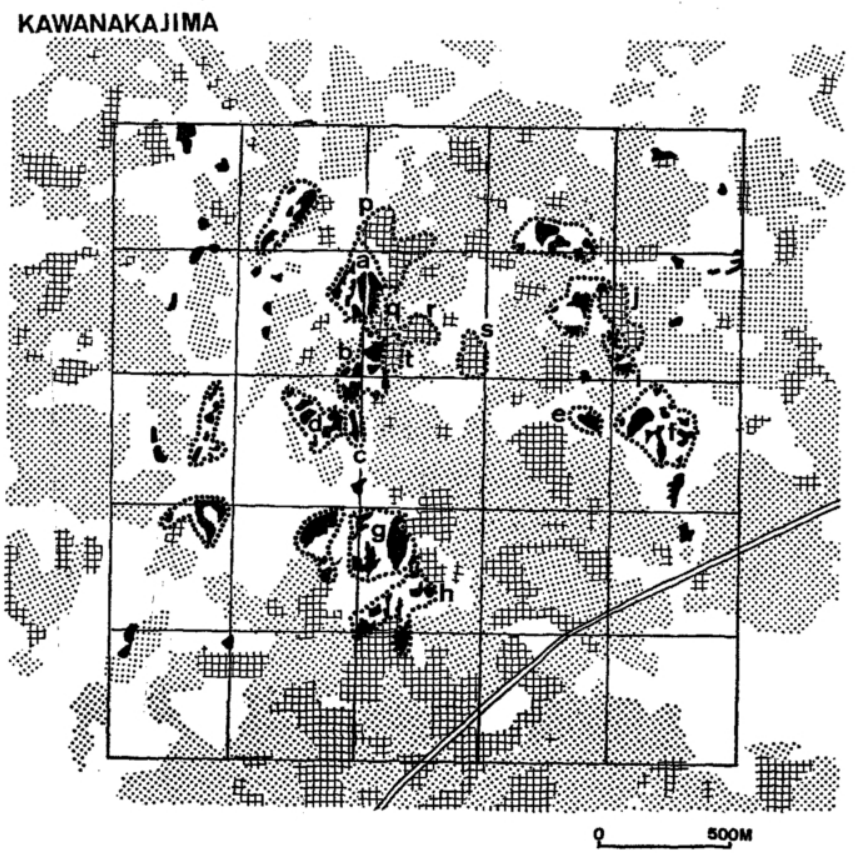

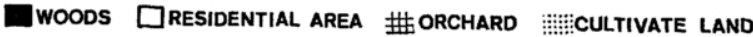

(b)

Fig. 1. Vegetation of study areas. Dotted lines show main areas of premises consisting of some houses and surrounding woods or areas of orchards, which are alphabetically named. 
結果

日詰と川中島常行寺での, 成鳥・亜成鳥のつくる群れの大きさの季節変化を Fig. 2 に示 した. 4 月から 9 月にかけての営巣行動もしくは栄立雛を含む群れが見られる期間と，9 月から 4 月にかけてのこれらがみられない期間が明確に区別できたので，前者を繁殖期， 後者を非繁殖期と呼ぶことにする.

非繁殖期の群れの大きさは調査地と年次を問わず 8-27 羽と大きく，冬の間に多少小さ くなるものが多いが, 比較的安定している. また, 日詰での 2 日を例外として, 両地とも に複数群がみられたことはない。なお日詰では, 例外的な 2 日を含めて，常にこの群中に 標識個体 $\mathrm{R}$ が含まれていた. 川中島常行寺でも，その年または前年の繁殖期に標識した特 定個体が含まれていることが多くの場合確認できた.

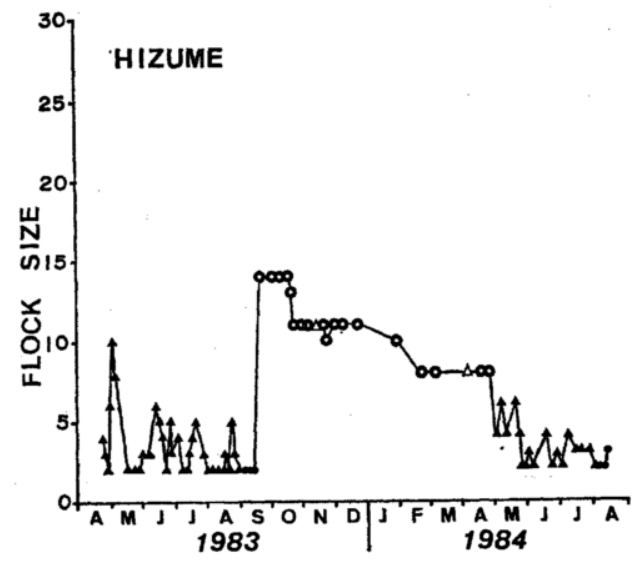

(a)

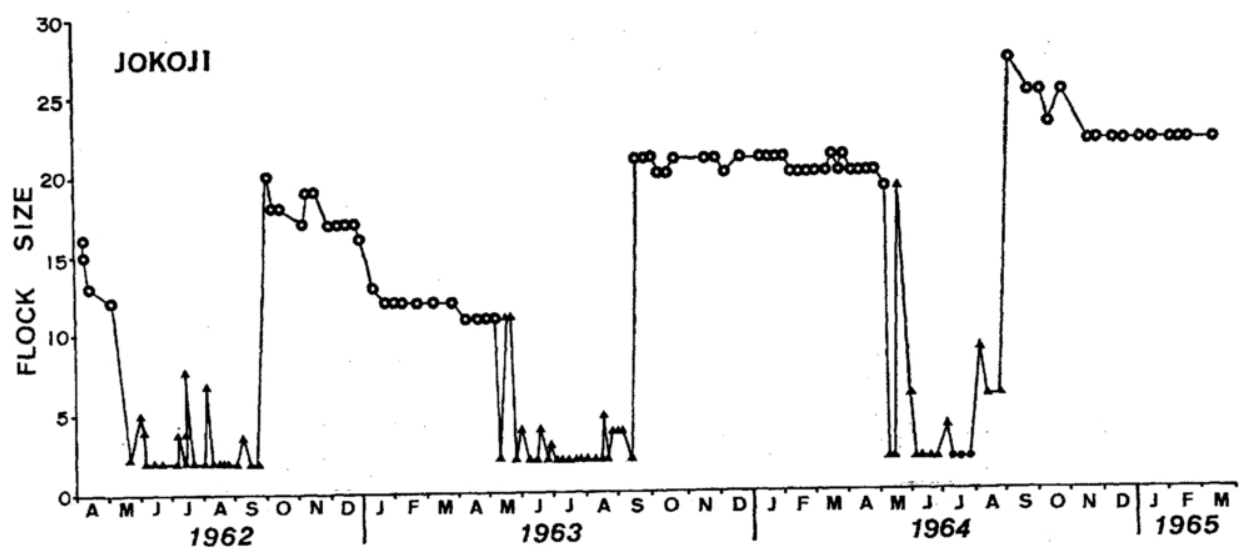

(b)

Fig. 2. Fluctuation of flock sizes including adults and young in the Hizume and Kawanakajima-jokoji flocks. Day's largest flock sizes are shown. Circles and triangles indicate observations of single flocks and plural flocks, respectively. Solid symbols indicate the breeding season. 
これに対して，繁殖期の群れはその半数以上 $(63 \%)$ が 2 羽から成り立っていた. しか し，繁殖期の当初には非繁殖期と同じ大きさの群れが見られたこともあり，さらに繁殖最 盛期ですら 5 羽以上の群れの見られることがあった.

以上のよらに, 非繁殖期のみならず繁殖期に拈いても, 群れの様相は異りながら,なお 群れが一年を通してみられることが明白である.

\section{1) 繁殖期}

i) 営巣時期

日詰と川中島常行寺における繁殖の経過は Fig. 3 に示す通りである. 日詰の 1983 年の 調査開始日 (4 月 24 日) には, すでに造巣活動が 1 つの巣で見られた。この後，5-10 日 の間隔で 6 月上旬まで 7 巣の造巣開始がみられ，その後 6 月下旬と 7 月下旬に各一つ ずつ造巣が開始され，計 9 巣がつくられた. 営巣活動は 9 月半ばにすべて終了した. ま た, 1984 年には造巣活動が 5 月上旬に開始され，以後 3-10 日の間隔で 5 月末まで計 4 巣が営まれ始め, 全営巣活動は 7 月半ばに終了した.

いっぽう, 川中島常行寺では, 後述のように巣の探索範囲が限られていたため, 全巣を 発見できなかった可能性があるが，発見できた限りでは以下の通りであった． 3 年ともに 5 月上旬に 1-10 日の間隔で造巣活動が始められ，1962・63 年にはその後約 1 か月ない しそれ以上において，それぞれ 1 巣が 6 月上旬あるいは 7 月中旬に開始されている。 こ らして営栄活動は $1962 ・ 63$ 年には 9 月上旬あるいは 8 月中旬に終了し, 1964 年には 7 月上旬に終了している.

繁殖成功率は日詰では約 62\%，川中島常行寺では約 42\% で，全体を通してみると $50 \%$ 弱の成功率となる。 また巣立の成功と営巣開始時期との間には，明確な関係は認められな

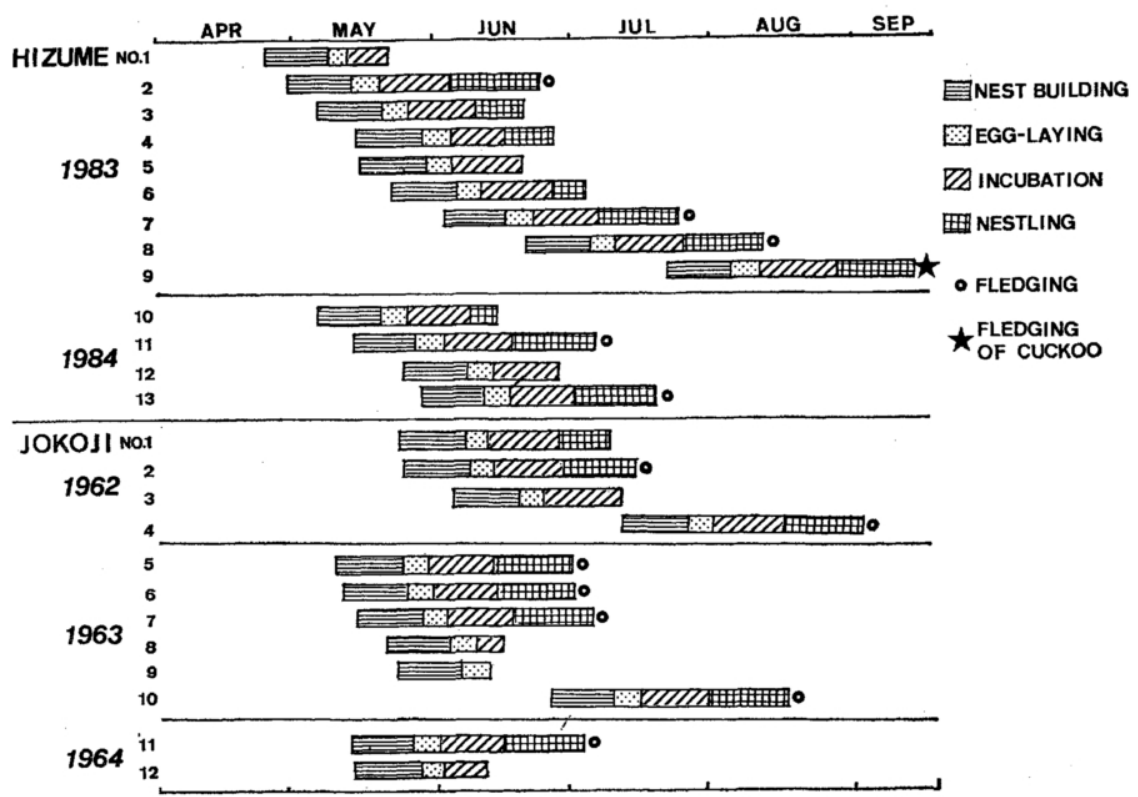

Fig. 3. Breeding stages in the Hizume and Kawanakajima-jokoji flocks. 
かった. な拉, 1983 年日詰の最後の営巣個体の巣からはカッコウ Cuculus canorus が巣立 ったが，これは 1 例であるため巣営時期との関係などは不明である.

な持日詰の No. 9 の営巣開始以前に巣 1-6 は営巣に成功しあるいは失敗している. し たがって,これらの巣の親がNo.9 の親である可能性は否定できない. 同様に, 川中島常行 寺の巣 10 の親が No. 8 と No. 9 である可能性もある.

ii) 巣の空間的配置

日詰における 9 巣 (1983 年) および 4 巣 (1984 年) はいずれも屋敷林 C につくられ ており, 他では巣はまったくみられなかった (Fig. 4a). 各巣間の距離は $1983 \cdot 84$ 年でそ れぞれ, $7 \mathrm{~m}$ (No. 3-No. 9 間)-175 m (No. 5-No. 6 間), $19 \mathrm{~m}$ (No. 10-No. 12 間)-120 m (No. 12-No. 13 間) であり, 最近隣巣までの平均距離 $(\mathrm{m} \pm \mathrm{SD})$ は, $31.4 \pm 30.7 \mathrm{~m}(n=9)$, $40.3 \pm 36.3 \mathrm{~m}(n=4)$ であった.

川中島常行寺における 1962-64 年の巣はいずれも屋敷林 a と b につくられ， 1 巣だけ が b に隣接したリンゴ園 q につくられた (1963 年). この場合, 少なくとも屋敷林 c, 果 樹園 $\mathrm{p} ・ \mathrm{r} ・ \mathrm{~s} ・ \mathrm{t}$ 飞はまったく営巣されていないことが確認してある. 3 年間の各巣間の距 離はそれぞれ, $20 \mathrm{~m}$ (No. 2-No. 3 間)-75 m (No. 2-No. 4 間), 最近隣巣までの平均距離 $(\mathrm{m} \pm \mathrm{SD}) 32.5 \pm 10.9 \mathrm{~m}(n=4), 30 \mathrm{~m}$ (No. 6-No. 10 間)-315 m (No. 8-No. 10 間), 55.0土 $17.0 \mathrm{~m}(n=6), 25 \mathrm{~m}$ であった.

Fig. 5 に日詰 1983 年の標識個体 R・M・S の空間利用状況を示した.

R (Fig. 5a) は，自分の巣 No. 4 を中心にほとんど屋敷林 C 内で活動していた. 時々隣 接する屋敷林 B・D やその近くへ出ているが，それ以外の林ではまったく見られなかっ た. 移動の際に他巣に接近したりその上空を通過しても (3 回観察), 攻撃を受けることは なかった。

M (Fig. 5b) む屋敷林 C の中でほとんど活動していた. また多くの巣の付近を通過して いるが, いずれの巣の周辺を通った場合も (8 回観察), 他個体との間に排他的行動は観察 されなかった. ただし， 7 月 1 日 (75 分間観察) に No. 8 の巣の東側のカキの木で $\mathrm{M} ・$ $\mathrm{S}$ と未標識の 2 羽との計 4 羽が集まったとき, M が未標識の 2 羽を追いかけた 1 例を 観察した. また $\mathrm{M}$ は 7 月 7 日には No. 2 の巣から巣立った幼鳥たちの 1 羽に給慨を した 1 例を観察した.な打 $\mathrm{M}$ は 7 月 14 日以後姿を消し, 続く非繁殖期の群れの中に もその姿はなかった.

S (Fig. 5c) もほとんど屋敷林 C の中で活動していた. この個体もやはり多くの巣の近

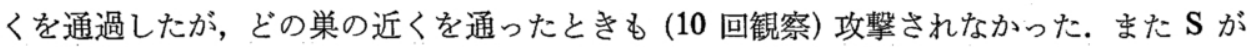
$\mathbf{R} \cdot \mathbf{M}$ と接近したときも (3 回観察), 攻撃行動は一切みられなかった.

未標識個体の記録地点もほぼ屋敷林 C とその周辺に限られていた (Fig. $5 \mathrm{~d})$. また, 多く のものが巣の近くを通過しているが，個体間に敵対行動はみられなかった。

なお， R は 1984 年にも屋敷林 C で営巣したが, 造巣行動を始めた 5 月 24 日から巣 を放棄した 6 月 24 日までの間, 巣を中心に他の 2 巣を含む半径約 $60 \mathrm{~m}$ の範囲でのみ 見られた. この間, 1983 年と同様に, 他の巣の周囲を攻撃を受けることなく動きまわって いた.さらに未標識の個体と R との間でも敵対行動は見られなかった.

iii) 家族群

巣立雛を伴っている 2 羽以上の成鳥 (以後家族群と呼ぶ) を, 日詰で 6 月23 日から 9 
月 10 日にかけて継続的に観察した. No. 2 と No. 8 の雛はそれぞれ，6 月 23 日-7 月 27 日と 8 月 10 日-8 月 30 日までの 35 日間と 20 日間, 家族群として調查地内で行動 していた (Fig. 6).

標識した No. 2 と No. 8 の家族群の巣立後の移動は Fig. 6 と示した通りで, 屋敷林

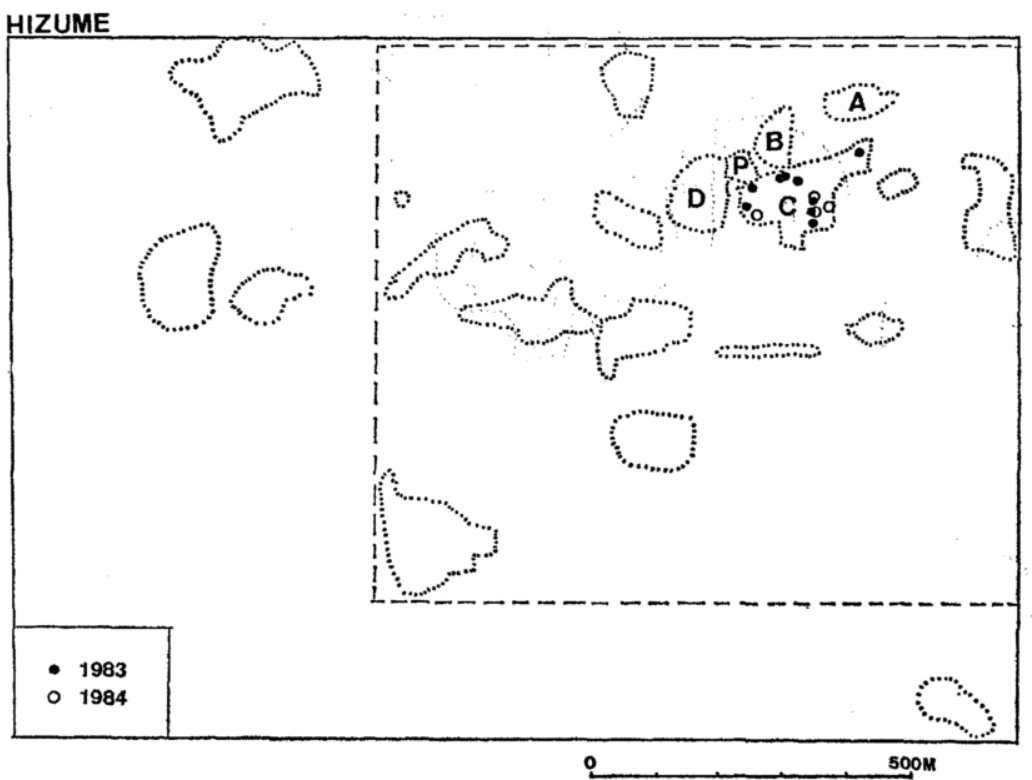

(a)

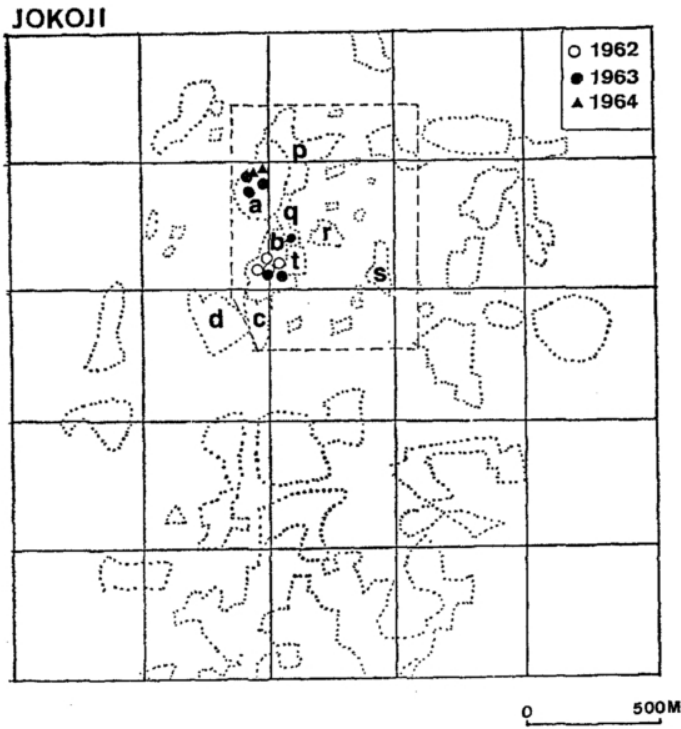

(b)

Fig. 4. Distribution of nests in the Hizume and Kawanakajima-jokoji flocks. Broken lines indicate areas of nest census. Dotted lines show premises or orchards. 


\section{BREEDING BIRD R}
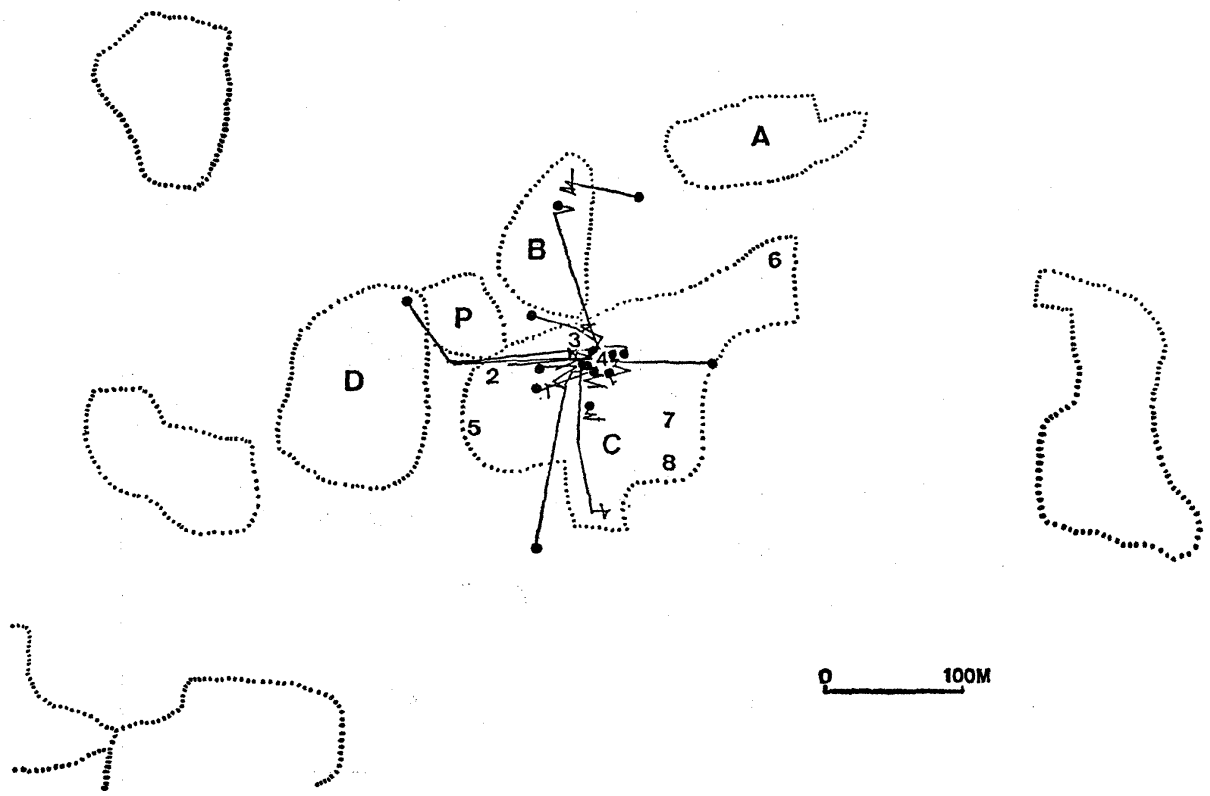

(a)

NON-BREEDING BIRD M
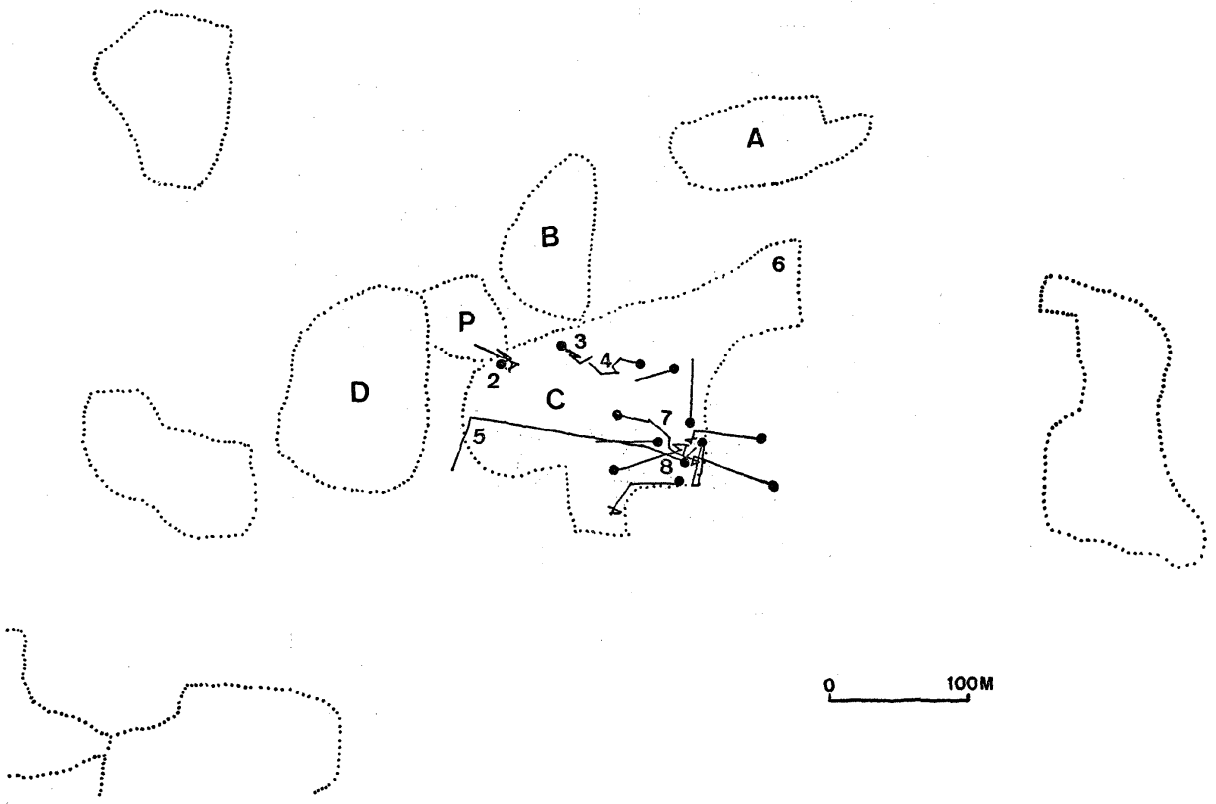


\section{NON-BREEDING BIRD S}
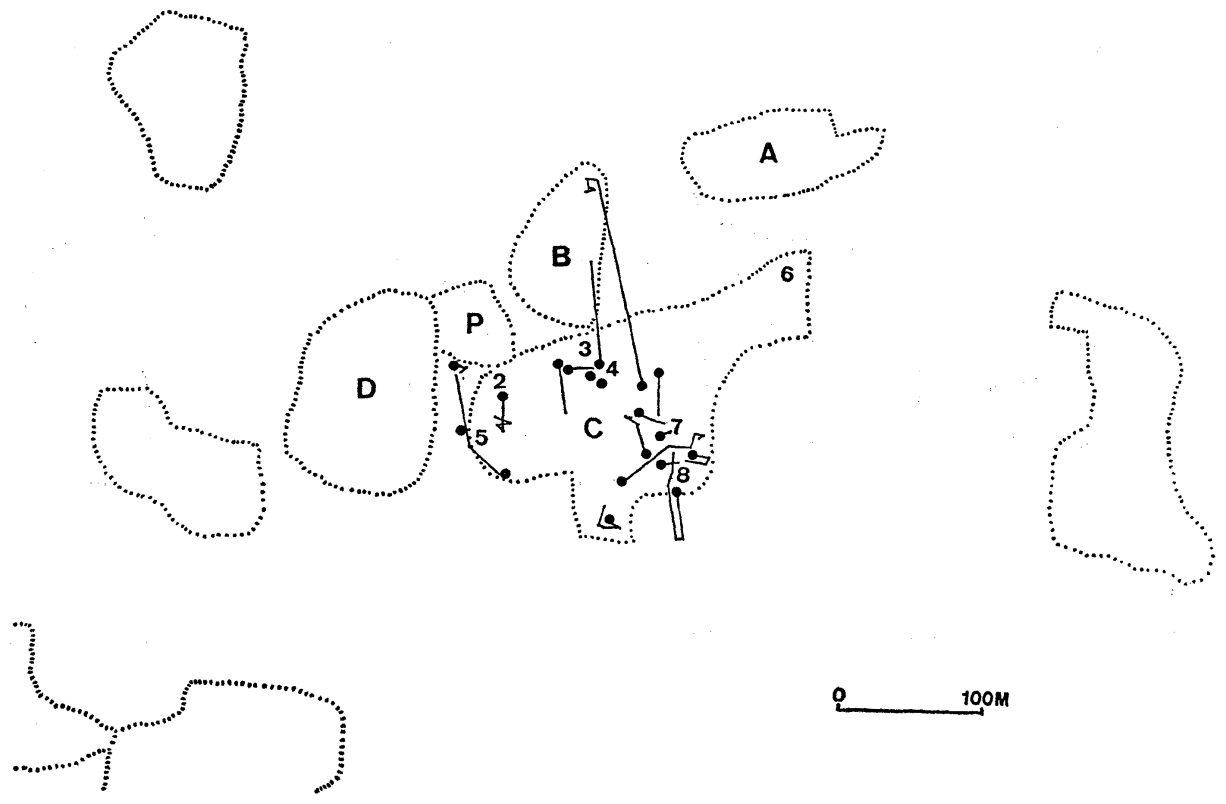

(c)

\section{ALL UNIDENTIFIED BIRDS}
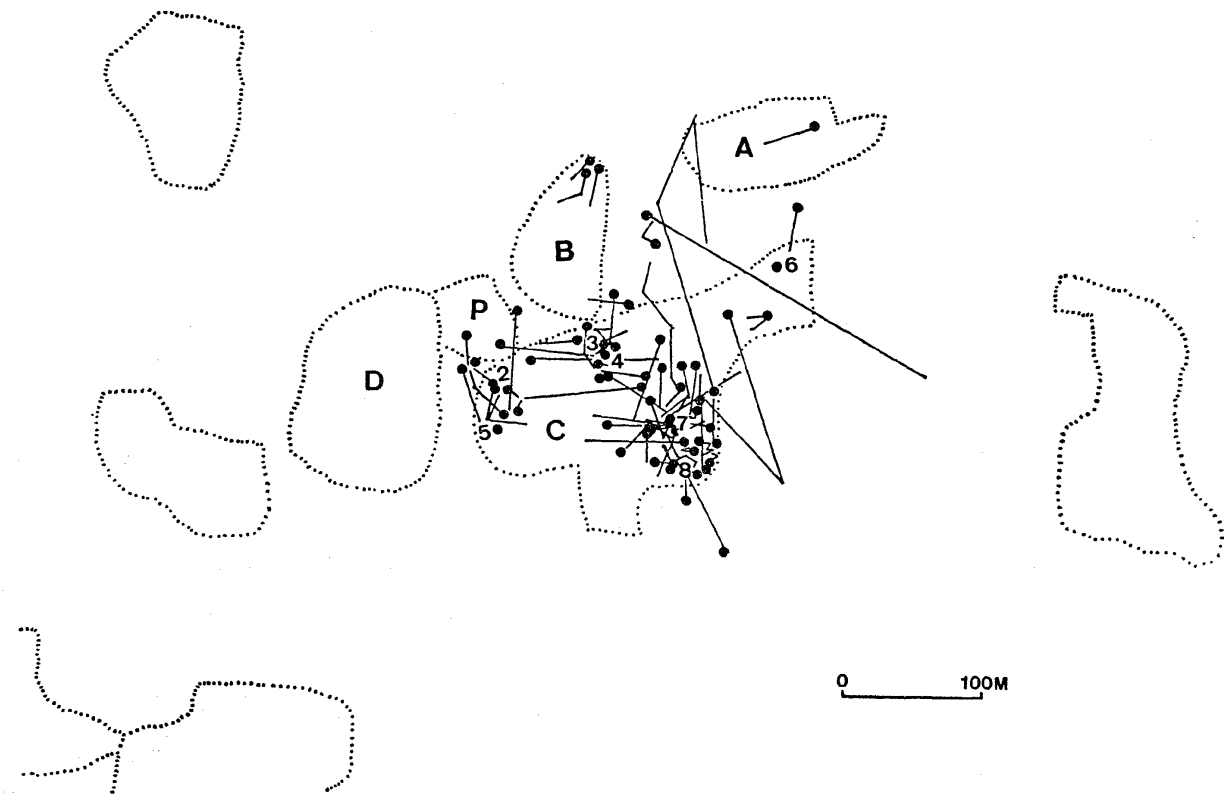

(d)

Fig. 5. Movements of individuals of the Hizume flock from June 13 to July 14, 1983, peak of breeding. Solid circles indicate detecting points. Figures show locations of nests. See Fig. 1 for dotted lines. 

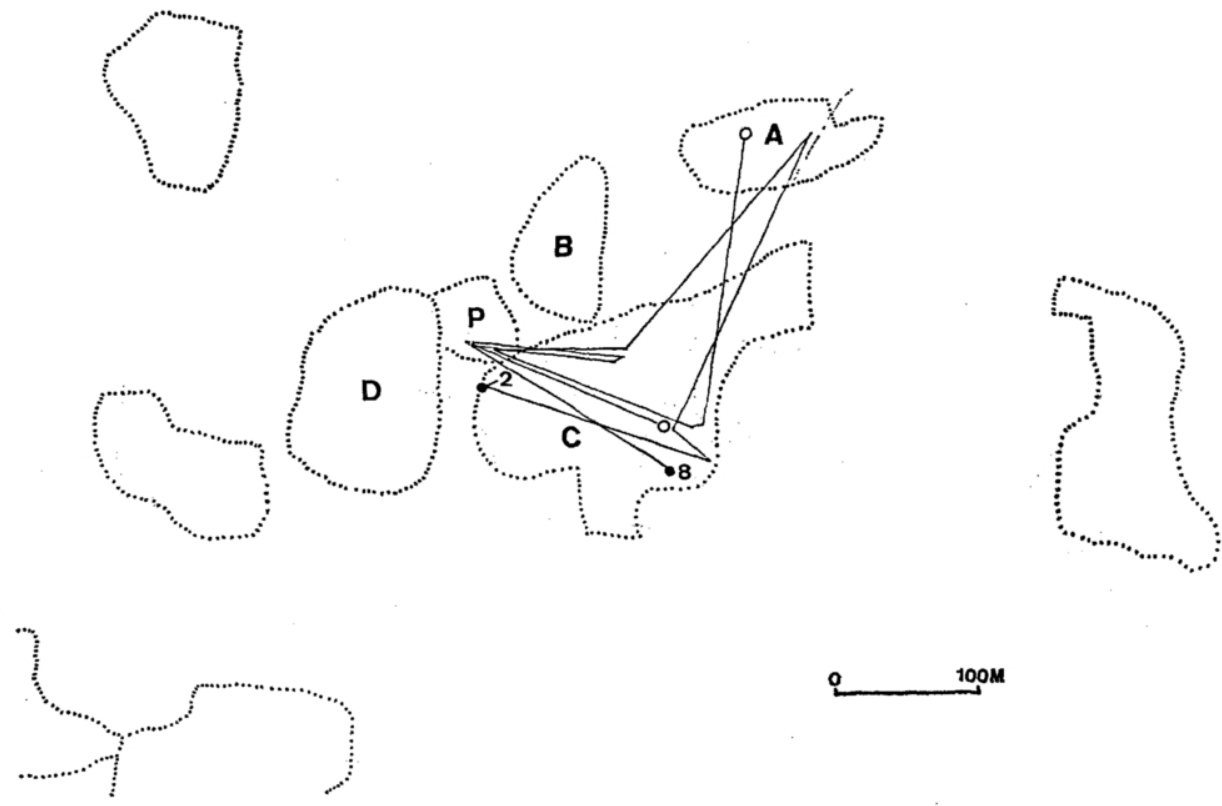

Fig. 6. Movements of the Hizume flock's families in 1983. Solid circles and open circles indicate observations and last observations after fledging, respectively. Family of nest No. 2 was observed from June 23 to July 14, and that of nest No. 8 from August 10 to 30. See Fig.1 for dotted lines.

$\mathrm{C} ・ \mathrm{~A}$ 版よ゙リンゴ園 $\mathrm{P}$ に限定されていた，幼鳥は一つの繁みでまとまって過ごし，親鳥 はとの周辺約 $30 \mathrm{~m}$ 内外の畑・リンゴ園・木立などで採䭒し, 幼鳥に䭒を運ぶのが通常で あった.

No. 2 と No. 8 の両家族群は, 巣立ち時期が上記のようにずれていたため相互に出会 うことがなかったが, No. 2 の家族群は 7 月 18-21 日の間に成鳥 2 羽と幼鳥 4 羽から なる未標識家族群と計 3 回 (1 時間 5 分) 出会い, No. 8 の家族群は 8 月 27.28 両日 に成鳥 3 羽と幼鳥 4 羽の未標識家族群と 2 回 (55 分間) 出会っている. そして, これら の家族を異にする幼鳥や親鳥の間には，排他行動は一度もみられなかった，その間幼鳥は それぞれの親鳥から給慨をされていた。

両家族群の就侍は 3 回継続的に観察した. 7 月 18 日に屋敷林 C の東側のエノキの木 にいた No. 2 の家族群 (成鳥 2 羽幼鳥 6 羽) が, 19 時 00 分に約 $50 \mathrm{~m}$ 西側に離れた ケヤキの梢に一斉に移り,すぐにまた先のエノキの木に戻り, つづいてその東側に隣接す るケヤキの梢に移動した. 時折りキュイキュイという小さな声がもれたが，19 時 10 分以 後は声も動きもまったく認められなくなった.

7 月 23 日 18 時 45 分にリンゴ園 $\mathrm{P}$ から No. 2 の巣の南側のケヤキの木へ, 標識鳥 $\mathrm{R}$ と未標識鳥の成鳥 2 羽幼鳥 3 羽から成る家族群が入った. 18 時 57 分に一団となって 屋敷林 C の中の東側の木立に移動し, 19 時 00 分には全個体がケヤキの木にまとまって 戻って来た. 木立に入った直後に 1 羽がギューイクィクィと 2 度鳴き, 以後まったく動 きはみられなかった.

さらに，8 月 28 日に屋敷林 $\mathrm{C}$ 中央のカヤの木で採食していた No. 8 の家族群 (成鳥 
2 羽幼鳥 3 羽) が， 17 時 53 分に成鳥 1 羽を先頭に全個体が西のリンゴ園 $\mathrm{P}$ へ入った. 18 時 23 分のギューイといら鳴き声を最後に, それ以後動きはみられなかった. なお, 家 族群が複数集って同一侍での就侍は観察されなかった.

このように家族群は構成員が 1 か所で就侍した.

iv)、繁殖期に見られる群れ

Fig. 2 に示したように, 繁殖期にも 3 羽以上の成鳥・亜成鳥が群れている状態がしばし ば観察されたが, これらは先にあげた家族群のほか, 移動中の群れ, 外敵などが現われた 際に生じる群れ, その他の一時的な群れ, 就侍のための群れ, に大別できる.

まず, 移動中の群れの記録はすべて, ある屋敷林（もしくはリンゴ園）から別の屋敷林 (もしくはリンゴ園) へ群れが移動するとき得られたものであるが, 群れが分れたり合した りすることはまったく観察されなかった. そこで群れの飛び立つ時期 (一斉か, 分散か) と 移動の経路 (同一か, 別か) によって区分してみたところ (Table 1), 1 例を除いてすべて 同一径路をとる一斉移動であり，例外は隣接した屋敷林とリンゴ園間でみたるので，最初 と最後の移動個体の時間差は 4 分であった.

つぎに, 群れによる外敵への攻撃があり, これは巣 2 (2 例)・7 (1 例)・8 (1 例) およ び No. 2 の家族群 (1 例) の周辺で見られ，ほとんどが巣の周辺で見られた. すなわち， 1983 年 6 月 14 日日詰で No. 2 の巣の雛に足輪を付けるために筆者が接近したときは, 6 羽の成鳥が集まって, 攻撃や威嚇を加えてきた. また, 巣の下を通ったネコや上空を通 ったハシボソガラス Corvus corone への 3-6 羽による攻撃が計 3 回みられた.

このような群れは, 1984 年の日詰に执いても, また川中島常行寺においてもしばしばみ られた。

さらにこれ以外にも，3 羽以上の個体の集合がしばしばみられた. 1983 年の日詰の例か らいくつかを挙げてみる.

6 月 26 日 6 時 20 分, 木立の中で 4 羽が集まって互いにギーギー鳴いていた. 6 月 6 日 18 時 50 分, 木に囲まれた芝生の庭で 3 羽が食物をとっていた。 そこへ 2 羽がやって来て， ともに食物を探し始めた。.とのうちに 2 羽はケヤキの木の梢の中に入り， 3 羽が残った. 6 月 16 日 6 時 33 分, No. 3 の巣の近くの電線に 4 羽が $30-50 \mathrm{~cm}$ の間隔でとまって いた. 端にいた標識鳥 $\mathrm{S}$ が 1 羽の隣りに入ると, この 1 羽が去り, 残った 2 羽のらち の 1 羽がもう 1 羽を追った. 6 月 22 日 6 時 10 分, $\mathrm{S}$ と末標識の 2 羽が電線に並ん

Table 1. Frequency of observations on movement types of the Hizume flock in the breding season. Flock members simultaneously or intermittently flied away through single or plural routes from areas of woods or orchards to others. Flock sizes are shown in parantheses.

\begin{tabular}{|c|c|c|c|c|}
\hline \multirow[b]{2}{*}{ Destination } & \multicolumn{2}{|c|}{ Simultaneous movement } & \multicolumn{2}{|c|}{ Intermittent movement } \\
\hline & $\begin{array}{c}\text { Single } \\
\text { route }\end{array}$ & $\begin{array}{l}\text { Plural } \\
\text { routes }\end{array}$ & $\begin{array}{l}\text { Single } \\
\text { route }\end{array}$ & $\begin{array}{l}\text { Plural } \\
\text { routes }\end{array}$ \\
\hline $\begin{array}{l}\text { Neighboring } \\
\text { area }\end{array}$ & $\begin{array}{c}5 \\
(8,7,6,5,5)\end{array}$ & 0 & 1 & 0 \\
\hline $\begin{array}{l}\text { Over neighboring } \\
\text { area }\end{array}$ & $\begin{array}{c}6 \\
(10,10,5,4,3,3)\end{array}$ & 0 & 0 & 0 \\
\hline Total & 11 & 0 & 1 & 0 \\
\hline
\end{tabular}


でとまっていた，やがて次々に下のグミの木へ下りてその実を啄み，別々に去った． 6 月 23 日 6 時 05 分, No. 4 の巣の隣りのケヤキの枝に 2 羽が並んでとまっていた. No. 4 の巣から出てきた標識鳥 $\mathrm{R}$ が近くにとまった. 2 羽のらち 1 羽が $\mathrm{R}$ に向って首を伸ば し, 翼を半開して震わしたが， $\mathrm{R}$ は応じなかった. しばらくして, かれらはとれぞれ別方 向へ去った. 6 月 25 日 4 時 40 分, メタセコイアの梢で 2 羽がギー・ギーと鳴いてい るところに, 屋敷林 $\mathrm{D}$ から飛来した $\mathrm{R}$ が加わって同様に繰返して鳴いた. 7 月 3 日 13 時 48 分, カキの梢近くの枝に標識鳥 $\mathrm{M}$ がとまっていた. そこへ 2 羽がやって来てとま り, 続いて 3 羽で下の庭へ入っていった.

このような一時的な集合の事例は，1984年の繁殖期および川中島常行寺の調査でもよく みられた。

最後に, 就侍の群れをあげることができる. 日詰で 2 番いが造巣開始した 1983 年 4 月 30 日に 8 羽の集団侍が, また繁殖最盛期の番いが抱卵や育雛にあたっていた 6 月 7 日 にも 6 羽の集団侍が，ともに屋敷林 $\mathrm{C}$ に発見されている.ちなみに，この時の雛を除く 総数はともに 12 羽であった。

また, 川中島常行寺では 2 番いが造巣を開始していた 1962 年 6 月 2 日 18 時 10 分 に, 屋敷林 $\mathrm{b}$ から 10 羽が連ってリンゴ園 $\mathrm{r}$ に入り, 18 時 50 分に全個体が揃って侍入り した. 同年 6 月 9 日には, 屋敷林 b で 2 番いが産卵期に, 1 番いが造巣期にあった. 18 時 1-5 分にリンゴ園 $\mathrm{r}$ に造巣期の 1 番いがいて, 別に 2 羽が採慨していたが, らち 1 羽 が屋敷林 bへ入った. 残りの 1 羽と造巣期の 2 羽の計 3 羽は, リンゴ園 $\mathrm{r}$ のほぼ中央 の木立に入ったまま活動を停止した. 18 時 38 分に, 屋敷林 b の木立から 5 羽が連って 先に 3 羽が入った木立に入って, そのまま動かなくなった. この後巣がある木立には個体 が一切みられなかったので, 営巣中の個体も侍に入ったと考兄られた. なお,この日の総 数は 8 羽であった.

同年 6 月 22 日には 2 番いが抱卵期にあった. この日 18 時 55 分に屋敷林 b の No. 2 の巣の抱卵中の個体に給䭒した個体がリンゴ園 $\mathrm{r}$ に入り, 続いて 4 羽が同じく No. 2 の巣のある木から出て次々とリンゴ園に入った. No. 1 と No. 2 の巣の中には各 1 羽が 残っていたので, これらの巣の番いの内の 1 羽は 5 羽の集団埘に加わったものとみられ る. 1962 年 7 月 14 日は No. 2 の巣の觹の巣立ち 1 日前であった. 雛に給慨をしたこ の巣の番いは, 雉を拈いたまま 19 時 10 分にリンゴ園 $\mathrm{r}$ へ向い, 先に別の 6 羽が入った 木立にいき，そこで 6 羽と共に㭙をとった. 翌朝 4 時 17 分には 8 羽の成鳥がこの侍か ら出て, このらちの 2 羽はそのまま No. 2 の巣へ直行した.

このように営巣中の番い, あるいはそのらちの 1 羽も集団侍に加わるのである.な拉, 就侍場所は葉が繁った木や木立で, 内部で小さく移動を繰返して, 同じ枝にはとまらずに 離れて眠る. 眠り枝の確保に関しては争いはみられなかった.

\section{2) 非繁殖期}

i）群れのまとまり

非繁殖期の群れの採食場所間の移動のしかたを日詰で 43 回観察した (Table 2). この場 合, 繁殖期に見られた同一経路をとる一斉移動・分散移動のほかに, 別経路をとる一斉移 動が 2 例見られた. これはともに, リンゴ園 $\mathbf{P}$ に人が接近した際に群れが驚いて屋敷林 へ移動したときのものであるが, 屋敷林 B 側にいた個体は B を経て C へ, 屋敷林 C 側 
Table 2. Frequency of observations on movement types of the Hizume flock in the nonbreeding season. See Table 1 for further explanations.

\begin{tabular}{lccccc}
\hline & \multicolumn{2}{c}{ Simultaneous movement } & & \multicolumn{2}{c}{ Intermitten movement } \\
\cline { 2 - 3 } \cline { 5 - 6 } Destination & $\begin{array}{c}\text { Single } \\
\text { route }\end{array}$ & $\begin{array}{c}\text { Plural } \\
\text { routes }\end{array}$ & & $\begin{array}{c}\text { Single } \\
\text { route }\end{array}$ & $\begin{array}{c}\text { Plural } \\
\text { routes }\end{array}$ \\
\hline $\begin{array}{c}\text { Neighboring } \\
\text { area } \\
\text { Over neighboring } \\
\text { area }\end{array}$ & 12 & 2 & 8 & 0 \\
Total & 19 & 0 & 2 & 10 & 0 \\
\hline
\end{tabular}

にいた個体は直接 C へ移動した. また分散移動の場合の先頭の個体と最後の個体の時間 差は 3-6 分程で, 繁殖期と殆ど変らない.すなわち, 移動に当って群れは固くまとまって いた.

このようなまとまりの強さは, 群れの構成羽数が終日安定していることからも明白であ る. 例光ば, 1962 年 10 月 7 日 5 時 22 分から 16 時 35 分まで常行寺群を連続追跡し た結果によれば，個体は常に 18 羽で変らず，しかもそのまま帱に入った.

次に非繁殖期の時の状況を Table 3 に示した. 就侍個体数は, 殆ど当日の群れの大きさ と同数であることがわかる. しかし，日詰では 2 月から 4 月，川中島では 12 月から 3 月にしばしば就侍個体数が 2 倍程度，あるいはそれ以上に大きくなる場合がみられた.

これは, 例えば 1962 年 12 月 9 日に川中島常行寺でみられたように, 昼間と同じ大き さの 17 羽が No. 6 の時に入った後, 別方向からやってきた 26 羽が同じ埘に入ってきた ことを確認したことからも明らかなように, 複数の別の群れが共同で形成するものである. このような複数の群れが共同でとる侍を複合侍と呼ぶことにする.

㭙の位置は, 日詰でも川中島でも通常の㭙は屋敷林 C のその周辺, 屋敷林 $\mathrm{a} ・ \mathrm{~b}$ あるい は $\mathrm{a} ・ \mathrm{~b} ・ \mathrm{q}$ の周辺にあるのに対して, 複合等はそれらからかなり遠く離れた場所に位置す る (Fig. 7). 例外は川中島の埘 6 が屋敷林 $\mathrm{a}$ にあるのに, 12 月に複合侍が形成された 2 例である.な怙日詰の埘 8 と川中島の侍 10 は複合時との中間の距離にあって, 通常の埘 としても複合塒としても使われていた.

墛は, 日詰でも川中島常行寺でも, 継続して使用される傾向がらかがえる. 侍に使われ た樹種は, 日詰でも川中島でも常緑樹（サワラ・スギ・タケ）か落葉以前の広葉樹（ケヤ キ・リンゴ)に限られている.

就侍場所に入るに当っては, 縦の長い列になるか, 一団になってやって来て枝葉が密な 木や木立に入り，その後内部で移動を繰返して，同じ枝には止らずに分散して眠る．眠り 枝の確保に関しては，まれに個体間の争いがみられることがある.なお複合侍の場合も， 群れ間の争いはまったくみられなかった.

ii) 群れの場所利用

Fig. 8 は日詰でみられた群れの全移動経路である. 標識個体 R を含む群れ（以後 日詰 群と呼ぶ) の移動経路は, 屋敷林 C とこれに隣接する地域に集中しているが， O・L・K まで広がって拈り, 東西約 $1.2 \mathrm{~km}$ 南北約 $0.9 \mathrm{~km}$ の範囲を動いていることになる (Fig. 8a). またこれに隣接して 3 つの別群がみられたが (Fig. 8b)，これらの隣接群の利用地域 
Table 3. Use of roosts in the Hizume and Kawanakajima-jokoji flocks in the non-breeding season.

\begin{tabular}{|c|c|c|c|c|c|c|}
\hline & $\begin{array}{l}\text { Location } \\
\text { of roost }\end{array}$ & $\begin{array}{l}\text { Number of } \\
\text { roosted } \\
\text { birds }\end{array}$ & $\begin{array}{c}\text { Group } \\
\text { size }\end{array}$ & $\begin{array}{c}\text { Roosting } \\
\text { trees }\end{array}$ & $\begin{array}{l}\text { Number of } \\
\text { roosting } \\
\text { trees }\end{array}$ & $\begin{array}{l}\text { Size of } \\
\text { roosting } \\
\text { area }\left(\mathrm{m}^{2}\right)\end{array}$ \\
\hline \multicolumn{7}{|l|}{ Hizume } \\
\hline \multicolumn{7}{|l|}{1983} \\
\hline Oct. 10 & 5 & 14 & 14 & Сур & 12 & \\
\hline Oct. 22 & 5 & 11 & 11 & Сур & 12 & \\
\hline Oct. 29 & 2 & 11 & 11 & $\mathrm{Zel}$ & 2 & \\
\hline Nov. 13 & 2 & 11 & 11 & Zel & 2 & \\
\hline Nov. 20 & 6 & 11 & 11 & Crp, Сур & 15 & \\
\hline Nov. 27 & 6 & 11 & 11 & Crp, Сyp & 15 & \\
\hline Dec. 11 & 7 & 11 & 11 & Bam, Crp & 8 & \\
\hline Dec. 25 & 7 & 11 & 11 & Bam, Crp & 8 & \\
\hline \multicolumn{7}{|l|}{1984} \\
\hline Jan. 29 & 8 & 10 & 10 & Bam, Crp & 4 & \\
\hline Feb. 19 & 8 & 17 & 8 & Bam, Crp & 4 & \\
\hline Mar. 25 & 9 & 24 & 8 & Crp & 8 & \\
\hline Apr. 8 & 10 & 18 & 8 & Bam & 1 & \\
\hline \multicolumn{7}{|l|}{ Jokoji } \\
\hline \multicolumn{7}{|l|}{1962} \\
\hline Apr. 2 & 6 & 16 & 16 & Bam & & 280 \\
\hline Apr. 7 & 6 & 15 & 15 & Bam & & 280 \\
\hline Apr. 8 & 6 & 13 & 13 & Bam & & 280 \\
\hline May 6 & 7 & 12 & 12 & Crp & & 300 \\
\hline Oct. 1 & 1 & 20 & 20 & App & & 1100 \\
\hline Oct. 6 & 1 & 18 & 18 & App & & 1100 \\
\hline Oct. 7 & 1 & 18 & 18 & App & & 1100 \\
\hline Nov. 2 & 1 & 17 & 17 & App & & 1100 \\
\hline Nov. 6 & 1 & 19 & 19 & App & & 1100 \\
\hline Nov. 10 & 4 & 19 & 19 & App & & 1600 \\
\hline Nov. 11 & 4 & 19 & 19 & App & & 1600 \\
\hline Dec. 2 & 13 & 54 & 17 & Bam, Crp & & $(9000)$ \\
\hline Dec. 8 & 13 & 44 & 17 & Bam, Crp & & $(9000)$ \\
\hline Dec. 9 & 6 & 43 & 17 & Bam & & 280 \\
\hline Dec. 22 & 14 & 60 & 17 & Bam & & 140 \\
\hline Dec. 23 & 14 & 51 & 16 & Bam & & 140 \\
\hline \multicolumn{7}{|l|}{1963} \\
\hline Jan. 5 & 13 & 78 & $11+$ & Bam, Crp & & (9000) \\
\hline Jan. 12 & 7 & 13 & 13 & Crp & & 300 \\
\hline Jan. 29 & 10 & 64 & 12 & Bam, Cyp & & $(7800)$ \\
\hline Jan. 31 & 10 & 12 & 12 & Bam, Сyp & & $(7800)$ \\
\hline Feb. $\quad 1$ & 10 & 12 & 12 & Bam, Сур & & $(7800)$ \\
\hline Feb. 16 & 10 & 31 & 12 & Bam, Сyp & & $(7800)$ \\
\hline Mar. 9 & 15 & 37 & 12 & Bam & & 150 \\
\hline Mar. 23 & 6 & 12 & 12 & Bam & & 280 \\
\hline Apr. 6 & 6 & 11 & 11 & Bam & & 280 \\
\hline Apr. 21 & 6 & 11 & 11 & Bam, Cyp & & 280 \\
\hline Apr. 29 & 8 & 11 & 11 & Bam, Crp & & 1250 \\
\hline May 4 & 8 & 11 & 11 & Bam, Crp & & 1250 \\
\hline May 7 & 8 & 11 & 11 & Bam, Crp & & 1250 \\
\hline
\end{tabular}


Table 3. Continued.

\begin{tabular}{|c|c|c|c|c|c|c|}
\hline & $\begin{array}{l}\text { Location } \\
\text { of roots }\end{array}$ & $\begin{array}{l}\text { Number of } \\
\text { roosted } \\
\text { birds }\end{array}$ & $\underset{\text { size }}{\text { Group }}$ & $\underset{\text { trees }}{\text { Roosting }}$ & $\begin{array}{c}\text { Number of } \\
\text { roosting } \\
\text { trees }\end{array}$ & $\begin{array}{l}\text { Size of } \\
\text { roosting } \\
\text { area }\left(\mathrm{m}^{2}\right)\end{array}$ \\
\hline Sep. 17 & 3 & 21 & 21 & App & & 900 \\
\hline Sep. 23 & 3 & 21 & 21 & App & & 900 \\
\hline Sep. 29 & 3 & 21 & 21 & App & & 900 \\
\hline Oct. 5 & 5 & 20 & 20 & App & & 750 \\
\hline Oct. 12 & 5 & 20 & 20 & App & & 750 \\
\hline Oct. 17 & 5 & 21 & 21 & App & & 750 \\
\hline Nov. 16 & 8 & 21 & 21 & Bam & & 125 \\
\hline Nov. 30 & 1 & 21 & 21 & App & & 110 \\
\hline Dec. 6 & 11 & 20 & 20 & Bam & & 50 \\
\hline $\begin{array}{l}\text { Dec. } 21 \\
1964\end{array}$ & 6 & 45 & 21 & Bam & & 280 \\
\hline Jan. 11 & 16 & 49 & 21 & Bam & & 100 \\
\hline Jan. 18 & 16 & 54 & 21 & Bam & & 100 \\
\hline Jan. 19 & 16 & 79 & 21 & Bam & & 100 \\
\hline Jan. 28 & 16 & 48 & 21 & Bam & & 100 \\
\hline Feb. 11 & 16 & 51 & 21 & Bam & & 100 \\
\hline Feb. 15 & 16 & 51 & 21 & Bam & & 100 \\
\hline Feb. 29 & 16 & 42 & 20 & Bam & & 100 \\
\hline Mar. 7 & 16 & 49 & 20 & Bam & & 100 \\
\hline Mar. 26 & 10 & 20 & 20 & Bam, Cyp & & $(7800)$ \\
\hline Mar. 29 & 10 & 21 & 21 & Bam, Cyp & & $(7800)$ \\
\hline Apr. 5 & 12 & 20 & 20 & Bam, Crp & & 140 \\
\hline Apr. 11 & 12 & 20 & 20 & Bam, Crp & & 140 \\
\hline Apr. 11 & 12 & 20 & 20 & Bam, Crp & & 140 \\
\hline Apr. 25 & 9 & 20 & 20 & Bam & & 230 \\
\hline
\end{tabular}

Cyp $=$ Japanese cypress, $\mathrm{Crp}=$ cryptomeria, Zel=zelkova, App=apple, Bam =bamboo. See Fig. 7 for locations of roosts. Sizes of roosting areas in parentheses are much larger than others, because roosting trees in those areas are scattered.

は殆んど日詰群のそれと重複せず，日詰群との出会いもみられなかった.

日詰群のこの期間に拈ける屋敷林別の滞在状況を Table 4 に示した. 秋・冬を通じて滞 在時間が最も長いのは屋敷林 C であり (47.7\%), 次いで秋に B であり $(29 \%)$, この 2 か 所で総滞在時間の $71 \%$ 以上を占める. 冬には B のかわりに屋敷林 G が $17 \%$ に達し, その他とリンゴ園 P での滞在時間が減少するとともに，逆に秋には立ち寄らなかった屋敷 林 $\mathrm{F} ・ \mathrm{~N} ・ \mathrm{~K} ・ \mathrm{M} ・ \mathrm{O}$ に滞在がみられる. 屋敷林 B とリンゴ園 $\mathrm{P}$ での滞在時間の減少は エンジ・カキ・リンゴなどの実がこれらの場所でまったくなくなったことと対応している のであろら.また $\mathrm{A}$ は秋冬とも, これらについでょく利用されている.

1 回当りの滞在時間でみても, 屋敷林 $\mathrm{C}$ が著しく長く, ついで B・G・P・A の順とな る (Table 5). つぎに各林で各個体の行っている行動をまとめ, Table 6 に示した，採食・ 休息・羽づくろい・水飲み・水浴といった行動のすべてが秋冬ともに屋敷林 C で， その 殆どが秋に B でみられている. これに対して他の林は， G で若干の他の行動がみられた だけで，その他の屋敷林は専ら採食だけに利用されていることがわかる.

これを林自体の状況と対比してみると，高木が多数存在するのは屋敷林 $\mathrm{C} ・ \mathrm{~B} ・ \mathrm{G} ・ \mathrm{H}$ 


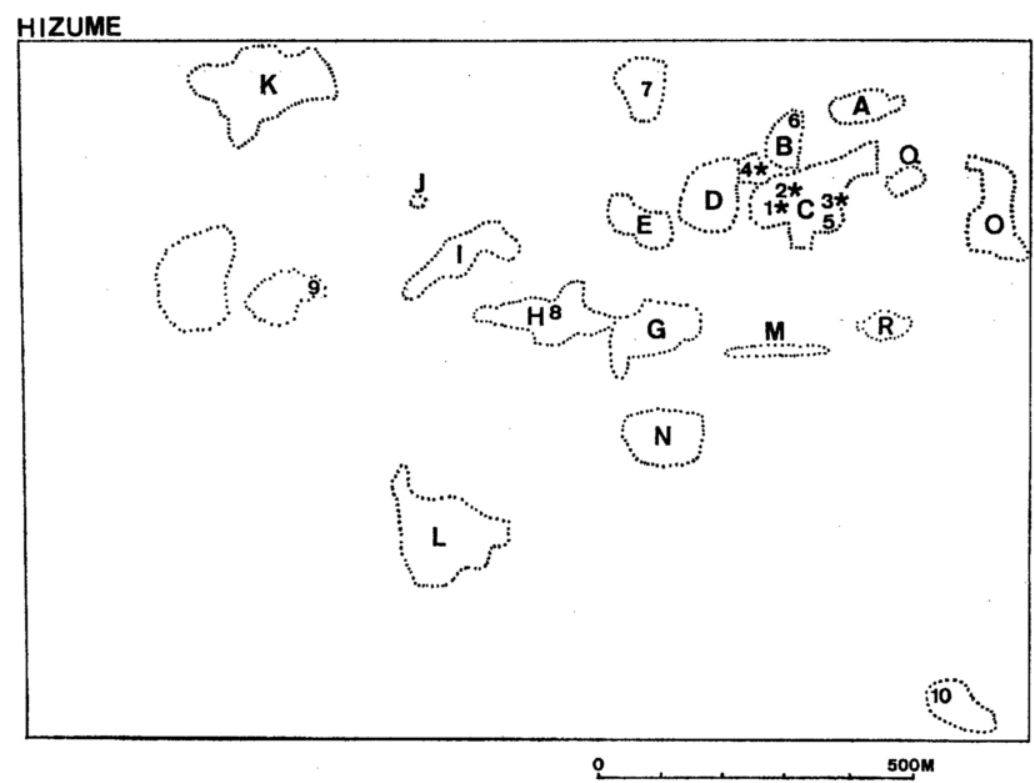

(a)

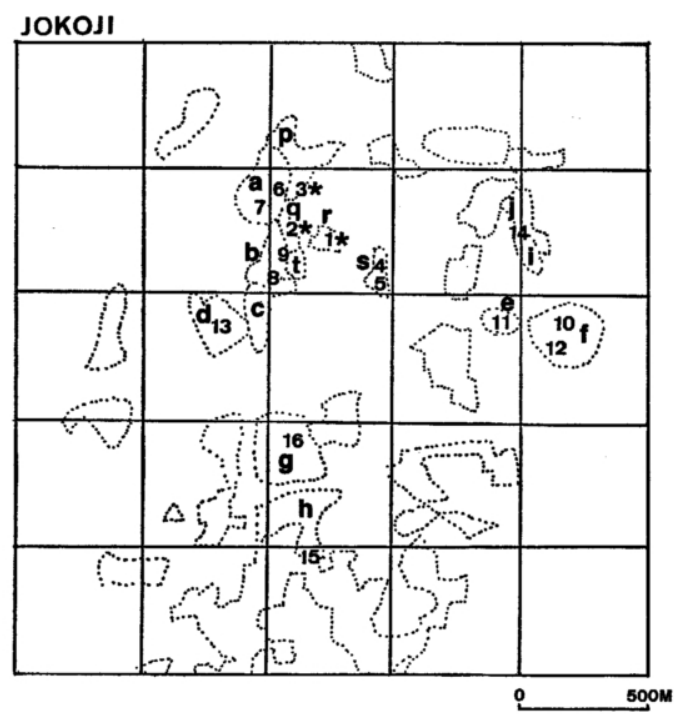

(b)

Fig. 7. Distribution of roosts in the Hizume and Kawanakajima-jokoji flocks in the nonbreeding season. Figures show locations of roosts. Roosts with asterisks were also used in the breeding season. See Fig. 4 for dotted lines.

のみであるが, このらち $\mathrm{H}$ はスギが一列に植えられたもので, 上部は幹が裸出して繁み がない.すなわち， C・B・G のみが大木の枝が相互に接した繁みが存在するところであ る.またりンゴ園 $\mathrm{P}$ は，樹高こそ小さいが，枝は落葉するまでは重なりあって全域を覆っ 


\section{HIZUME FLOCK}

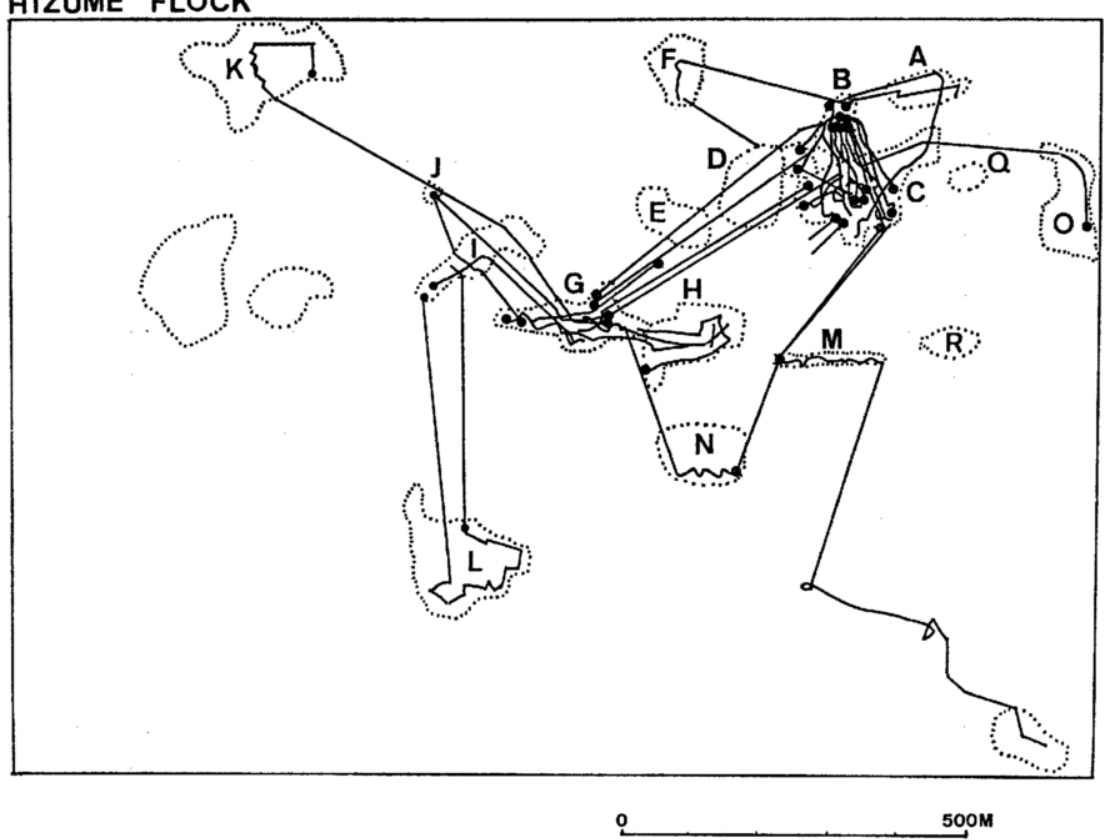

(a)

\section{OTHER FLOCKS}

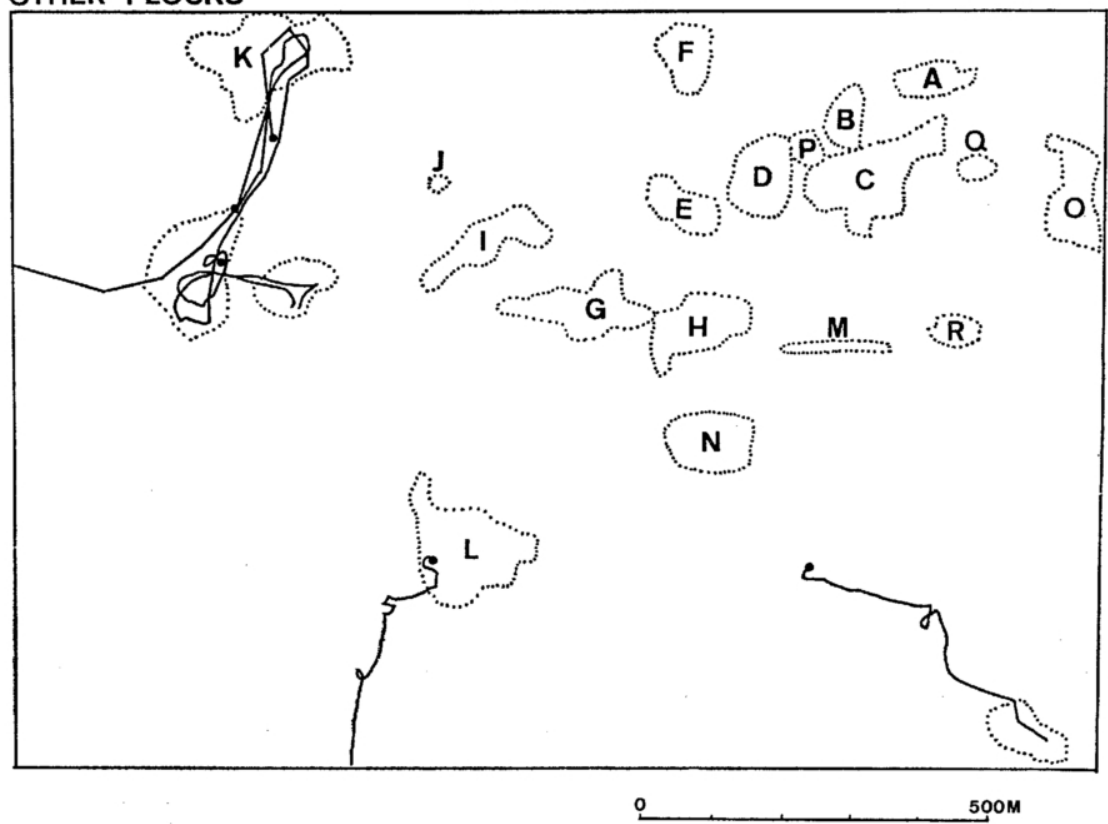

(b)

Fig. 8. Movements of flocks at Hizume in the non-breeding season, from 17 September 1983 to 29 April 1984. Solid circles indicate detecting points. See Fig. 1 for dotted lines. 
Table 4. Frequency of observations and percentages of staying time of the Hizume flock in woods or orchards. ${ }^{1}$

\begin{tabular}{|c|c|c|c|c|c|c|c|}
\hline \multirow{2}{*}{\multicolumn{2}{|c|}{$\begin{array}{l}\text { Area of woods } \\
\text { or orchard }\end{array}$}} & \multicolumn{3}{|c|}{ Freq. of observations } & \multicolumn{3}{|c|}{ Staying time $(\%)$} \\
\hline & & \multirow{2}{*}{$\frac{\text { Autumn }}{1}$} & \multirow{2}{*}{$\frac{\text { Winter }}{1}$} & \multirow{2}{*}{$\begin{array}{c}\text { Total } \\
2\end{array}$} & \multirow{2}{*}{$\begin{array}{c}\text { Autumn } \\
2.9\end{array}$} & \multirow{2}{*}{$\begin{array}{c}\text { Winter } \\
4.1\end{array}$} & \multirow{2}{*}{$\begin{array}{r}\text { Total } \\
3.1\end{array}$} \\
\hline Woods & A & & & & & & \\
\hline & B & 9 & 1 & 10 & 28.8 & 0.7 & 23.3 \\
\hline & $\mathrm{C}$ & 15 & 5 & 20 & 47.8 & 47.3 & 47.7 \\
\hline & D & 0 & 0 & 0 & - & - & - \\
\hline & E & 0 & 0 & 0 & - & - & - \\
\hline & $\mathbf{F}$ & 0 & 1 & 1 & - & 6.5 & 1.3 \\
\hline & G & 3 & 3 & 6 & 7.1 & 17.0 & 9.1 \\
\hline & $\mathbf{H}$ & 1 & 1 & 2 & 0.8 & 6.5 & 1.9 \\
\hline & I & 1 & 1 & 2 & 1.0 & 1.7 & 1.1 \\
\hline & $\mathbf{J}$ & 1 & 1 & 2 & 0.8 & 0.7 & 0.8 \\
\hline & K & 0 & 1 & 1 & - & 4.4 & 0.9 \\
\hline & $\mathbf{L}$ & 1 & 0 & 1 & 1.6 & - & 1.3 \\
\hline & $\mathbf{M}$ & 0 & 2 & 2 & - & 4.1 & 0.8 \\
\hline & $\mathbf{N}$ & 0 & 1 & 1 & - & 5.4 & 1.1 \\
\hline & 0 & 0 & 1 & 1 & - & 1.7 & 0.3 \\
\hline \multirow[t]{3}{*}{ Orchard } & $\mathbf{P}$ & 4 & 0 & 4 & 9.1 & - & 7.3 \\
\hline & Q & 0 & 0 & 0 & - & - & - \\
\hline & $\mathbf{R}$ & 0 & 0 & 0 & - & - & - \\
\hline Total & & 36 & 19 & 55 & 100.0 & 100.0 & 100.0 \\
\hline
\end{tabular}

1 See Fig. 1 for locations of areas of woods or orchards.

Table 5. Staying time of the Hizume flock in woods or orchards. ${ }^{1}$

\begin{tabular}{|c|c|c|c|c|c|}
\hline \multirow{2}{*}{\multicolumn{2}{|c|}{$\begin{array}{l}\text { Area of woods } \\
\text { or orchard }\end{array}$}} & \multicolumn{4}{|c|}{ Freq. of observations } \\
\hline & & \multirow{2}{*}{$\frac{<20 \mathrm{~min}}{1}$} & \multirow{2}{*}{$\frac{20-40 \mathrm{~min}}{1}$} & \multirow{2}{*}{$\frac{>40 \mathrm{~min}}{0}$} & \multirow{2}{*}{$\frac{\text { Total }}{2}$} \\
\hline Woods & A & & & & \\
\hline & B & 5 & 2 & 3 & 10 \\
\hline & $\mathrm{C}$ & 7 & 5 & 8 & 20 \\
\hline & G & 4 & 0 & 2 & 6 \\
\hline Orchard & $\mathbf{P}$ & 2 & 0 & 2 & 4 \\
\hline
\end{tabular}

1 See Fig. 1 for locations of areas of woods or orchards.

Table 6. Behavior of the Hizume flock in woods or orchards. ${ }^{1}$

\begin{tabular}{|c|c|c|c|c|c|c|c|c|}
\hline \multicolumn{2}{|c|}{$\begin{array}{c}\text { Area of } \\
\text { woods or } \\
\text { orchard }\end{array}$} & \multirow{2}{*}{$\frac{\text { Foraging }}{++}$} & \multirow{2}{*}{$\begin{array}{r}\text { Resting } \\
--\end{array}$} & \multirow{2}{*}{$\begin{array}{c}\begin{array}{c}\text { Preen- } \\
\text { ing }\end{array} \\
---\end{array}$} & \multirow{2}{*}{$\begin{array}{c}\begin{array}{c}\text { Shelter- } \\
\text { ing }\end{array} \\
--\end{array}$} & \multirow{2}{*}{$\begin{array}{c}\begin{array}{c}\text { Drink- } \\
\text { ing } \\
\text { water }\end{array} \\
--\end{array}$} & \multirow{2}{*}{$\begin{array}{c}\begin{array}{c}\text { Tempo- } \\
\text { ral } \\
\text { staying }\end{array} \\
--\end{array}$} & \multirow{2}{*}{$\begin{array}{c}\begin{array}{c}\text { Roost- } \\
\text { ing }\end{array} \\
---\end{array}$} \\
\hline Woods & A & & & & & & & \\
\hline & B & ++ & +- & +- & +- & -- & ++ & +- \\
\hline & $\mathrm{C}$ & ++ & ++ & ++ & ++ & ++ & ++ & ++ \\
\hline & G & ++ & -- & -- & ++ & ++ & -- & -+ \\
\hline Orchard & $\mathbf{P}$ & +- & -- & -- & -- & -- & -- & +- \\
\hline
\end{tabular}

1 Mathematical symbols on left and right indicate observations in autumn and winter, respectively: $+=$ observed, $-=$ not observed. See Fig. 1 for locations of areas of woods or orchard. 


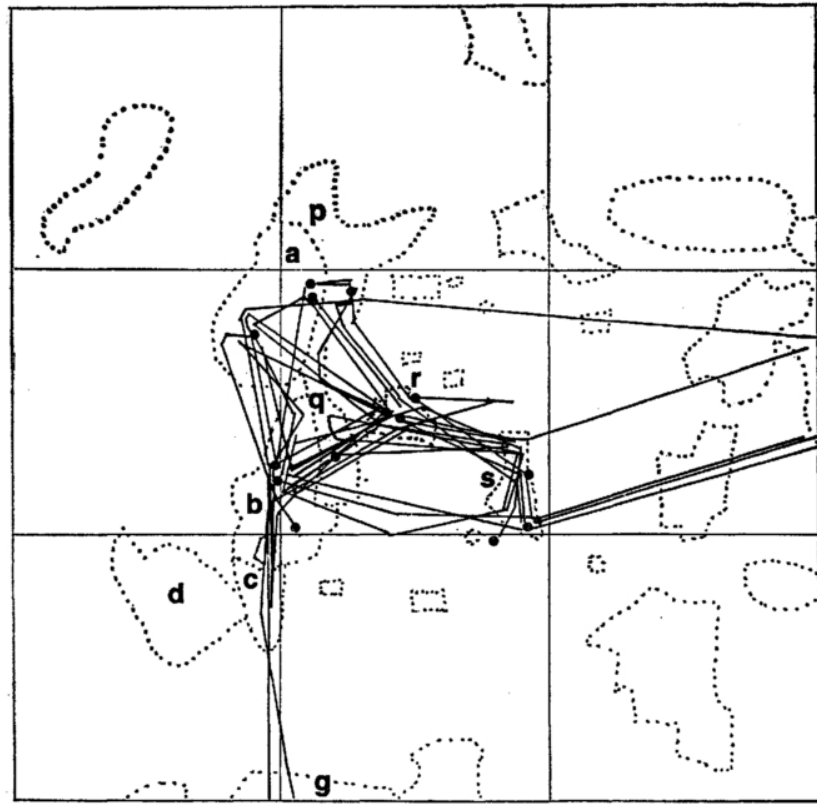

0

$500 \mathrm{M}$

Fig. 9. Movements of Kawanakajima-jokoji groups in non-breeding season, from October 1, 1962 to May 7, 1963. Solid circles indicate detection points. Upper nine meshes of Fig. 1 are drawn out. See Fig. 1 for dotted lines.

ている. したがって，葉が繁って外部からも林の内部からも見えない隱蔽性に富んだ林が よく利用される.

つぎに, 川中島常行寺の 1962-63 年にかけての非繁殖期の群れの全移動経路を Fig. 9 に 示した. 移動経路は屋敷林 $\mathrm{a} ・ \mathrm{~b}$ とリンゴ園 $\mathrm{r} ・ \mathrm{~s}$ を中心に, それにリンゴ園 $\mathrm{p} ・ \mathrm{q}$ を加 えた範囲にまとまっているが，これらの場所から $500 \mathrm{~m}$ 以上離れた屋敷林 $\mathrm{e} ・ \mathrm{f}$ などにし ばしば埘をとったため, 侍への経路が南方と東方に伸びて図示されている. 就侍のための ものを除く行動範囲は東西約 $0.6 \mathrm{~km}$ 南北 $0.5 \mathrm{~km}$ であり, 日詰群と比べてかなり小さい (媵を加えると東西 $1.5 \mathrm{~km}$ 南北 $1.5 \mathrm{~km}$ 程度となる).

1983 年の非繁殖期の川中島には 4 つの異った群れの存在することが，1-3 月の調査に おいても (Fig. 10a), 3 月 13 日に行った 9 人の観察者による同時調査でも (Fig. 10b), 明らかになった. またこの間, 群れ間の出会いが数回観察された. A 群と B 群の行動範囲 の重複する地域を利用したのを A 10 回, B 6 回観察したが, このうち 3 回両群が出会 った.

1 月 15 日, B 群 23 羽が分散して採食していた屋敷林 b へ, 14 時 25 分に A 群 19 羽が一団となって飛んできた. しかし， A 群は北側のリンゴ園の上空で進路を変え, 北方 へ戻った.この際 B 群には迎撃行動はまったくみられず, その後南へ採食しながら移動し ていった.

1 月 29 日, B 群が採食していた屋敷林 a の南端のスギ木立に A 群 18 羽のらち, ま ず 12 羽が北から一団で入ってきた. このときスギ木立の中で $\mathbf{A}$ 群による激しいキュイキ 
ユイといら声が起り, B 群全 23 羽は屋敷林 b へ, 2 分後にはさらに南へ飛んだ. B 群が 去った後，A 群からはピルルルルといら鳴き声が起り，そのまま a 内で採食し，16 時 40 分に全個体が北方へ去った.

2 月 19 日, 屋敷林 a の南端のスギ木立で採食していたA 群 17 羽が, 13 時 40 分に 約 $100 \mathrm{~m}$ 北東の木立へ移った. 2 分後に, 屋敷林 $\mathrm{b}$ の北端の木立の南側で分散採食して いた B 群の中の 5 羽が, 屋敷林 a の南端へ飛来した. 残りは屋敷林 b にそのま留っ ていた，飛来した 5 羽を直ちに $\mathrm{A}$ 群の 6 羽が，まず飛んできた 2 羽を南方へ追い，さ らに木立へ戻った後, このらちの 5 羽で木立内に残った 3 羽を追跡し，これも 1 分後に は南方へ飛び去った. その後 $\mathrm{A}$ 群の 5 羽は, スギの木の梢の横枝に集まりカタカタ (咽 音）と鳴いた.な抏， A 群の残りの個体は北東の木立に残ったままであった.

このように両方の群れが出会らと一方の群れの攻撃・追い払いあるいは回避行動がみら れた。

\section{論議}

非繁殖期のオナガは, 日詰・川中島常行寺の両調查地とも 1 日に 1 群しか見られず, その群れの大きさは日中はもちろん, 日が違っても比較的安定しており，そこには常に同 一の標識個体が入っていた．また採食場所間の移動状況をみても，群れはきわめてま之ま りが良かった. さらに, 就侍個体数は複合塮で 2 群以上が合流することがあっただけで, 日 中の群れの大きさと同じであった，周囲の群れと行動圈を殆んど重ねず，またとの境界域 においても殆んど出会らことがなく, 出会った場合は避け, あるいは敵対的であった. こ れらのことは, 非繁殖期のオナガが同一の構成員から成る固定的な群れとして生活し， あ る範囲を安定した群れの行動圈あるいは群れなわばりとして保有している,つまり典型的 な群れ単位の生活者であることを示している.

それでは繁殖期はどうであろうか.オナガは一夫一妻で繁殖する種であり（細野 1966a， 1971a,), また番いと見られる 2 羽単位の行動がよくみられたが, いっぽらで各番い同士は 空間的によくまとまって営巣していた。 また営巣個体はもちろん, 繁殖個体も巣のある屋 敷林を中心に, 比較的狭い範囲に生活空間を限定していた。しかも他の番いの巣の付近を 平気で通過し，かつ個体間の排他行動はほとんどみられなかった，さらに，移動時や攻撃 時には 3 羽以上の群れがよく見られ，繁殖失敗個体や非繁殖個体が他の家族群に同行する など，日中には群れ行動が頻繁に見られた.

こうした群れの状態は夜間にも引き継がれて集団侍に至る. 繁殖期間であっても非繁殖 個体 (若鳥) が集団で侍をとることは, 例えばカササギ Pica pica やキバシカササギ Pica nattlli などでも知られている (久保 1959, VERVEEK 1973). しかしオナガの場合は, 先に 示したように，営巣中の番いの雌雄の片方ないし双方もまた集団㭙に加わるのである.

すなわら群れ生活の部分を保っている．いやむしろ，群れがいくらか持続しながら番い に別れているというよりも，止むを得ないときにのみ番いに分れるかたちが断続的に見ら れるのであって, 繁殖期もまた基本的には群れで生活しているのだと言った方が，オナガ の生活形態を表現するのにはむしろふさわしいのではあるまいか.

日詰では, 非繁殖期には広い範囲を群れの行動圏としているのに対して, 繁殖期には屋 敷林 C に巣が限られ，またその行動範囲はこの屋敷林の範囲に限定されていた．この屋敷 
JAN 15 - MAR 12, MAR 14-19, 1983

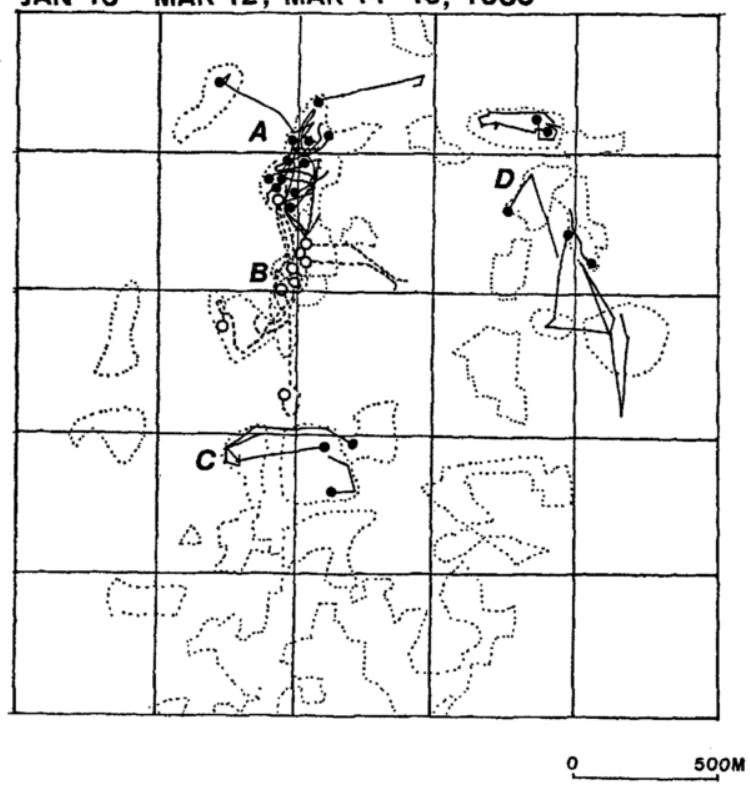

(a)

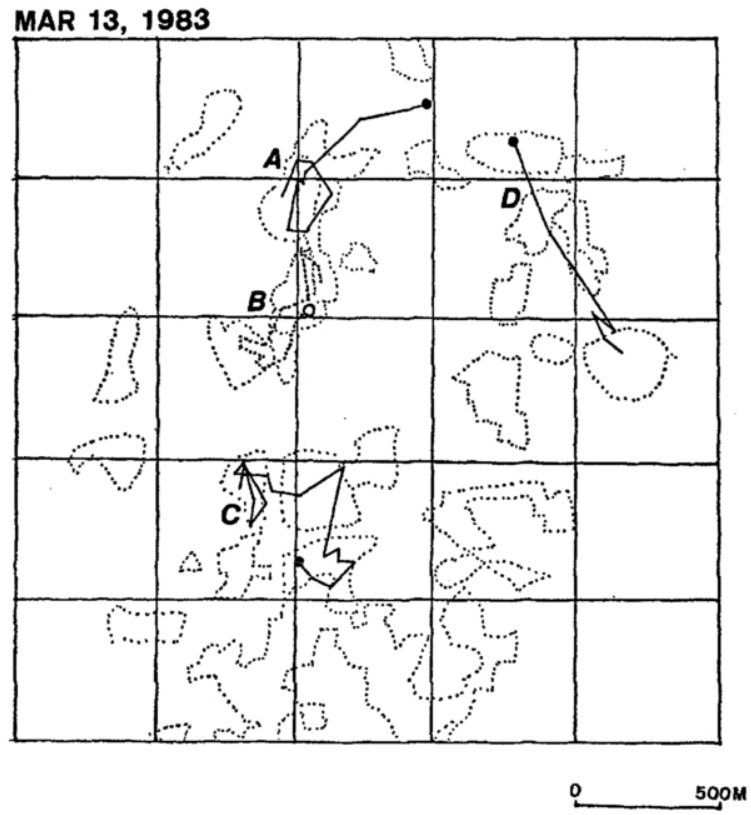

(b)

Fig. 10. Movements of Kawanakajima groop in non-breeding season. Circles indicate detecting points. See Fig. 1 for dotted lines. 
林 C は非繁殖期の群れの行動圈全体 (最小面積で $266,000 \mathrm{~m}^{2}$ ) からみると, $1.8 \%$ の面積 を占めるにすぎないが，群れの場所利用の面からは秋・冬の非繁殖期を通して滞在時間で $50 \%$ 近く，またさまざまな行動内容がみられる唯一の場所である.すなわち日詰の群れの 非繁殖期の行動圏は広く, 繁殖期は狭いけれども, 群れが主要に使っている場所 (センタ 一) は一年中変らないのである.

川中島常行寺の群れに拈いても，繁殖期と非繁殖期の行動範囲のちがいは同様であり， 非繁殖期の行動圏の大きさ (最小面積で $290,000 \mathrm{~m}^{2}$ ) も日詰と殆ど变らない.ただ巣営場 所としては屋敷林 $\mathrm{a} ・ \mathrm{~b}$ とリンゴ園 $\mathrm{q}$ が，また冬にはこの他にリンゴ園 $\mathrm{r} ・ \mathrm{~s}$ が比較的均 等に利用されている.

日詰と川中島常行寺でのこのような違いは何によるものであろらか. 川中島では樹木の 状況を詳しく調査していないのだが, 日詰では小さい屋敷林・リンゴ園が多数分散して存 在し, その面積や質に大きな差があったのに対して, 川中島常行寺の屋敷林や果樹園はと もに大きくかつ比較的近接していることは確かである.こうした差がオナガの場所利用に 影響を与えているのかもしれない.

さて, 周年 20 羽内外の小群で生活する鳥類の社会構造については, わが国ではエナガ (中村 [登] 1957, 1962, 1969，1972) についてょく研究されている. エナガは造巣期のはじ めにも, 巣造りのために番いで過す時間はわずかで, 大半は群れで過しており, 夜は群れ で塒に入る. さらに育雊期の後半からは番い群になり, 家族群, さらに合同群をへて, 冬 の群れになる.すなわち, 造巣後半から育雛期にかけての時期を除いて, 周年群れている わけである. なた「群れなわばり」をもち, 冬季には集団壀をとり, 侍場所は此較的安定し ていること, さら繁殖期にも巣が比較的集中し, ヘルパーが存在するなど, オナガの群 れと似ているところが多い.しかしエナガの場合は, 繁殖期には重複は存在するとはいえ 番いなわばりを確立して抒り, 巣の外壁が完成すると番いの雌雄は必ず巣の中で一緒に眠 り，これは育雛中期まで続く(中村 [登] 1972)。これに対して，オナガの番いは先にのべた ように巣を集中してつくり，互いに排他性を示さない。すなわち番いなわばりを持たず， 繁殖期を通じて群れ行動や一時的な集合がみられ, さらに営巣中の親がある場合は双方と もに集団侍に加わるなど, 繁殖期にもエナガよりはるかに徹底した群れ性を示している.

オナガのよらに堅固な群れ性を示す鳥は, 世界中でこれまで他に明示されたことがない. ただメキシコカケス Aphelocoma ultramarina の長期にわたる個体識別された個体群につ いて, 直径約 $0.5 \mathrm{~km}$ の群れの行動圈内に $2(-5)$ 巣がまとまって作られ, 群れのほとんど すべてが複数の巣へ通って育篗に従うへルパー制度をもっている (BROWN 1963, 1981). 就 侍行動についてはほとんど記載がないし，また年中 5-22 羽の群れで生活するとあるが, 非繁殖期の資料は一切示されていないのだが，ヘルパーのあり方からみれば，オナガの社 会よりもっと徹底した群れ生活者であるのかもしれない。

鳥類の群れは，現在まで多くの資料を示し徹底して論じられたことは少ないのだが，群 れと一口に言っても, その内容は, すでに述べたようにオナガに限ってさ光, 多岐にわた っている. 今後は, 群れがぞのような生活内容を示すものかをはっきり区別したうえで, それぞれの群れの構造や機能に関する論議を進める必要があろう. 
1) 1983-84 年に長野市日詰でままた 1962-65 年 (および 1983 年冬) 飞長野市川中島で，オナガの 個体相互の関係や群れの関係などその社会構造を, 全季節を通じて調べた。

2) 番いや家族群がみられる時期を繁殖期 (4 月-9 月) とし，それ以外を非繁殖期とした.

3) 非繁殖期の群れは 20 羽内外でまとまりをもって移動し, 1 日の群れの大きさは終日变らなかっ た.

4）侍はつねに群れの全構成員でとられ，冬から春にかけては 2-3 群の合同した複合侍が形成され ることがあった. この場合㭙での群れ間の闘いはみられなかった.

5) 非繁殖期の日詰の群れの行動圈は東西約 $1.2 \mathrm{~km}$, 南北約 $0.9 \mathrm{~km}$ であり, 18 個の屋敷林を含 んでいた. 屋敷林ごとの滞在時間や利用頻度は, 屋敷林の環境条件と密接に関連していた.

6) 非繁殖期の群れ間には, 行動域のごく一部しか重複がみられず, またここでは回避や追払い行 動がみられた.すなおち群れの行動圈は群れなわばりである.

7） 日詰群では各番いの巣は特定の屋敷林一か所に集中していた. 非繁殖期の群れなわばりを構成 した各個体は巣の間を自由に行動し，個体相互間に間怙きや敵対行動はみられなかった.

8）群れなわばりを構成している異性個体が番いになり, 営巣期は 4 月末から 9 月初めまでで, 巣 立率はほぼ $50 \%$ 弱であった. また, 家族群は 5 月半ばから 9 月半ばにみられ, 巣立ち後の約 1 か 月は巣の周辺の屋敷林での及過し, 夜はまとまって侍をとった.

9）家族群同士が出会っても相互に排他行動はみられなかった. 家族群には, 繁殖失敗の成鳥が付 随したり, 亜成鳥による雛への給䬲の手伝い行動がみられた.

10)家族群以外にも, 繁殖期を通じて移動時や外敵出現にあたっては, 全群とは限らないが群れで 行動した. また, 繁殖期にも侍は全員によるとは限らないが集団でとられ, 巣中の片親あるいは両親 が, 繁殖ステージによってこの集団㭙に参加した.

11）以上をるとに, オナガの生活形態や社会構造などを, 他の群れ生活をする鳥類と比較した. そ の結果オナガは, 確実な資料を持って論じられた鳥の中では, 群れ生活を年間を通して行ならすっと も典型的なるのであることが判った.

\section{SUMMARY}

1) The social system of Azure-winged Magpies Cyanopica cyana was studied at Hizume, Nagano City, from 1983 to 1984, and at Kawanakajima, Nagano City, from 1962 to 1965 and in winter of 1983.

2) The six months from April to September were defined as the breeding season, because pairs with or without their fledglings were observed during this period.

3) In the non-breeding season, flocks consisting of about 20 magpies were formed and the size of each flock was stable throughout the day.

4) In the non-breeding season, all members of a flock always roosted together. In winter and spring, different flocks sometimes roosted together without any antagonistic behavior.

5) The home range of Hizume flock was $1.2 \mathrm{~km}$ long and $0.9 \mathrm{~km}$ wide, and included 18 units of premises consisting of some houses and surrounding woods. Magpies spent longer time in premises with closed woods than those with sparse woods.

6) Home ranges of flocks seemed to coincide nearly with territories, because the home ranges overlapped little with each other and chases were observed around the boundaries of the ranges.

7) Flocks broke up into some pairs, non-breeding adults and subadults in the breeding season. At Hizume, nests of pairs belonging to the same winter flock were built $10-20 \mathrm{~m}$ apart from each other in a unit of premises, and the flock members visited the nests without any antagonistic behavior.

8) The fledging rate was nearly $50 \%$. Families consisting of pairs and their fledglings were 
observed from mid-May to mid-September. Family members moved and roosted together in the nesting woods about one month after fledging.

9) There was no antagonistic behavior between families of the same flock. Some adults which had failed in breeding joined families, and one subadult fed fledglings as a helper.

10) Even in the breeding season, not only pairs but also some non-breeding adults and subadults of the same flock sometimes moved or roosted together. They showed defensive behavior against conspecific intruders or natural enemies such as domestic cats and crows.

11) As a conclusion of comparison among group-living birds, the Azure-winged Magpie was considered as a typical species which formed stable flocks throughout the year.

\section{引用文 献}

Araujo, J., 1975. Estudios sobreel rabilargo (Cyanopica cyanea) en une colonia de cria de avila. Ardeola 21: $469-485$

Brown, J. L., 1963. Social organization and behavior of the Mexican Jay. Condor 65: 126153.

Brown, J. L., \& E. R. Brown, 1981. Extended family system in a commnal bird. Science 211: 959-960.

Goodwin, D., 1977. Crows of the world. St. Lucia, University of Queensland Press.

細野哲夫, 1966a. オナガの生活史に関する研究 (1). 繁殖 1. 山階鳥研報 4: 327-347.

- 1966b. オナガの生活史に関する研究 (3). 解の食性. 山階鳥研報 4: 481-487.

- 1967a. オナガの生活史阅する研究. 第 2 報 就侍行動 (1). 山階鳥研報 5: 34-47.

- 1967b. オナガの生活史に関する研究 (4). 群れの移動生活. 山階鳥研報 5: 177-193.

- 1968. オナガの生活史に関する研究 (5). 冬季持配直と地域群分布. 山階鳥研報 5: 278-286.

- 1969. オナガの生活史に関する研究 (6). 長野県内に批ける分布と移動 I. 山階鳥研報 5: 659-

675.

1971a. オナガの生活史に関する研究 (7). 繁殖 2. 山階鳥研報 6: 231-249.

1971b. オナガの生活史に関する研究 (8). 常行寺オナガ群生息地の鳥相環境. 山階鳥研報 6:

250-259.

- 1973. オナガの生活史に関する研究 (9). 就侍行動 (2). 山階鳥研報 7: 56-72.

- 1975. オナガの生活史に関する研究 (10). オナガと他種の関係. 山階鳥研報 7: 533-549.

1983. オナガの生活史に関する研究 (11). 繁殖手伝い特よびカッコウの託卵などについて.

山階鳥研報 15: 63-71.

清棲幸保, 1952. 日本鳥類大戝鑑 1, 3. 東京, 講談社.

久保浩洋, 1959. カササギの社会. 動物の社会と個体: 43-48. 東京, 岩波書店.

䓪精一, 1942. オナガの食性汇関する調査. 鳥獣調査報告 10: 129-242.

中村浩志, 1976. カワラヒワ Carduelis sinica 個体群の繁殖地へのすみつき. 生理生態 17: 273-282.

—1979. カワラヒワ Cardulis sinica の夏季の集合と換羽. 鳥 28: 1-27.

NAKAMURA, H., 1979. Habitat differences among resident and migratory populations of Oriental

Greenfinch Carduelis sinica groups in winter season. Misc. Rep. Yamashina Inst. Ornithol.

11: 53-82.

1982. Pair-fomation and territory establishment of the Oriental Greenfinch Carduelis sinica in autumm (Aves: Fringillidae). Physiol. Ecol. Japan 19: 15-56.

中村登流, 1957. 冬季エナガ群の移行生活に関する観察. 野鳥 22 (5): 251-259.

- 1962. エナガの蕃殖期生活の観察. 山階鳥研報 3: 155-173.

- 1969. エナガの個体群の行動圈構造. I 冬期群の行動圏と群れテリトリー。 山階鳥研報 5:

433-461.

- 1972. エナガの個体群の行動圏構造. II 繁殖期の行動とテリトリアリズム. 山階鳥研報 6: 424-488.

SAITou, T., 1978. Ecological study of social organization in the Great Tit, Parus major L. I. Basic structure of the winter flocks. Jap. J. Ecol. 28: 199-214.

- 1979a. Ecological study of social organization in the Great Tit Parus major L. II. Formation of the basic flocks. Misc. Rep. Yamashina Inst. Ornithol. 11: 137-148. 
SAItou, T., 1979b. Ecological study of social organization in the Great Tit, Parus major L. III. Home range of the basic flocks and dominance relationship of the members in a basic flock. Misc. Rep. Yamashina Inst. Ornithol. 11: 149-171.

1979c. Ecological study of social organization in the Great Tit, Parus major L. IV. Pair formation and establishment of territory in the members of basic flocks. Misc. Rep. Yamashina Inst. Ornthol. 11: 172-188.

SAntos, J. R. Dos. Jr., 1968. The colony of Azure-winged Magpies in the Barca d' Alva region. Cyanopica 1: 9-28.

Svensson, L., 1984. Identification guide to European passerines. 3 rd ed. Stockholm, Naturhistoriska Riksmuseet.

Verbeek, N. A. M., 1973. The exploitation system of the Yellow-billed Magpie. Univ. Calif. Publ. Zool 99: 1-58.

山岸哲, 1978. ホオジロの社会構造と繁殖つがい数の安定性: 山階鳥研報 10: 109-299.

YAMAGISHI, S., 1971. A study of the home range and territory in the Meadow Bunting (Emberiza cioides). Misc. Rep. Yamashina Inst. Ornithol. 6: 355-388.

Yamagishi, S, \& M. Fujioka, 1986. Heavy brood parasitism by the Common Cuckoo Cuculus canorus on the Azure-winged Magpie Cyanopica cyana. Tori 34: 91-96.

山階芳麿, 1933. 日本の鳥類とその生態 1. 東京, 出版科学総合研究所. 